\title{
Syntheses, Electrochemical, Linear Optical, and Cubic Nonlinear Optical Properties of Ruthenium Alkynyl-Functionalized Oligo(phenylenevinylene) Stars
}

\author{
Zhiwei Chen, ${ }^{[a]}$ Christopher J. Jeffery, ${ }^{[b]}$ Mahbod Morshedi, ${ }^{[b]}$ Graeme J. Moxey, ${ }^{[b]}$ Adam Barlow, ${ }^{[b]}$ \\ Xinwei Yang, ${ }^{[b]}$ Bandar A. Babgi, ${ }^{[b, c]}$ Gulliver T. Dalton, ${ }^{[b]}$ Michael D. Randles, ${ }^{[b]}$ Matthew K. Smith, ${ }^{[b]}$ Chi \\ Zhang, ${ }^{[a]}$ Marek Samoc, ${ }^{[d]}$ Marie P. Cifuentes, ${ }^{[a, b]}$ Mark G. Humphrey ${ }^{*[a, b]}$ \\ Contribution to the Special Issue of ChemPlusChem celebrating the Singapore Golden Jubilee. \\ Organometallic Complexes for Nonlinear Optics. Part 54. Part 53: H. J. Zhao, P. V. Simpson, A. Barlow, G. J. Moxey, M. Morshedi, \\ N. Roy, R. Philip, C. Zhang, M. P. Cifuentes and M. G. Humphrey, submitted.
}

\begin{abstract}
The syntheses of trans-[Ru(C $\equiv \mathrm{CC}_{6} \mathrm{H}_{4}-4-$ $\left.\mathrm{CHO})\left(\mathrm{C} \equiv \mathrm{CC}_{6} \mathrm{H}_{4}-4-\mathrm{R}\right)(\mathrm{dppe})_{2}\right]\left[\mathrm{R}=\mathrm{H} \mathrm{9a}, \mathrm{NO}_{2}\right.$ 9b, $\mathrm{CHO} 9 \mathbf{c}$, $\mathrm{C} \equiv \mathrm{CC}_{6} \mathrm{H}_{3}-3,5-\mathrm{Et}_{2} \quad 9 \mathrm{~d}, \quad(E)-\mathrm{CH}=\mathrm{CHC}_{6} \mathrm{H}_{4}-4-\mathrm{Bu}^{\mathrm{t}}$ 9e], trans$\left[\mathrm{Ru}\left(\mathrm{C} \equiv \mathrm{CC}_{6} \mathrm{H}_{4}-4-\mathrm{R}\right) \mathrm{Cl}(\mathrm{dppe})_{2}\right]\left[\mathrm{R}=\mathrm{C} \equiv \mathrm{CC}_{6} \mathrm{H}_{3}-3,5-\mathrm{Et}_{2}\right.$ 11a, (E)$\mathrm{CH}=\mathrm{CHC}_{6} \mathrm{H}_{4}-4-\mathrm{Bu}^{\mathrm{t}}$ 11b, (E) $-\mathrm{CH}=\mathrm{CHC}_{6} \mathrm{H}_{4}-4-\mathrm{NO}_{2}$ 11c], 1,2,4,5$\left.\left.\{\text { trans-[(dppe })_{2}\left(\mathrm{RC}_{6} \mathrm{H}_{4} \mathrm{C} \equiv \mathrm{C}\right) \mathrm{Ru}\left\{\mathrm{C} \equiv \mathrm{CC}_{6} \mathrm{H}_{4}-4-(E)-\mathrm{CH}=\mathrm{CH}\right\}\right]\right\}_{4} \mathrm{C}_{6} \mathrm{H}_{2}$ $\left[\mathrm{R}=\mathrm{H}\right.$ 14a, $\mathrm{C} \equiv \mathrm{CC}_{6} \mathrm{H}_{3}-3,5-\mathrm{Et}_{2}$ 14b, $(E)-\mathrm{CH}=\mathrm{CHC}_{6} \mathrm{H}_{4}-4-\mathrm{Bu}^{\mathrm{t}}$ 14c), $1-I-3,5-\left\{\text { trans }-\left[\left(\mathrm{L}_{2}\right)_{2}(\mathrm{R}) \mathrm{Ru}\left\{\mathrm{C} \equiv \mathrm{CC}_{6} \mathrm{H}_{4}-4-(E)-\mathrm{CH}=\mathrm{CH}\right\}\right]\right\}_{2} \mathrm{C}_{6} \mathrm{H}_{3} \quad\left(\mathrm{~L}_{2}=\right.$ dppm, $\mathrm{R}=\mathrm{Cl}$ 15a; $\mathrm{L}_{2}=$ dppe, $\mathrm{R}=\mathrm{C} \equiv \mathrm{CPh} 15 \mathrm{~b}, \mathrm{R}=\mathrm{C} \equiv \mathrm{CC}_{6} \mathrm{H}_{4}-4-$ $\mathrm{NO}_{2}$ 15c), 1-Me ${ }_{3} \mathrm{SiC} \equiv \mathrm{C}-3,5-\left\{\right.$ trans $-\left[\left(\mathrm{L}_{2}\right)_{2}(\mathrm{R}) \mathrm{Ru}\left\{\mathrm{C} \equiv \mathrm{CC}_{6} \mathrm{H}_{4}-4-(E)-\right.\right.$ $\mathrm{CH}=\mathrm{CH}\}]\}_{2} \mathrm{C}_{6} \mathrm{H}_{3}\left(\mathrm{~L}_{2}=\right.$ dppm, $\mathrm{R}=\mathrm{Cl}$ 16a; $\mathrm{L}_{2}=$ dppe, $\mathrm{R}=\mathrm{C} \equiv \mathrm{CPh}$ 16b), $\quad 1-\mathrm{HC} \equiv \mathrm{C}-3,5-\left\{\right.$ trans $-\left[(\text { dppe })_{2}(\mathrm{R}) \mathrm{Ru}\left\{\mathrm{C} \equiv \mathrm{CC}_{6} \mathrm{H}_{4}-4-(E)-\right.\right.$ $\mathrm{CH}=\mathrm{CH}\}]\}_{2} \mathrm{C}_{6} \mathrm{H}_{3}(\mathrm{R}=\mathrm{Cl}$ 17a, $\mathrm{R}=\mathrm{C} \equiv \mathrm{CPh}$ 17b) and 1,3,5-\{trans$\left.\left[(\text { dppe })_{2}\left(3,5-\mathrm{R}_{2}-\mathrm{C}_{6} \mathrm{H}_{3} \mathrm{C} \equiv \mathrm{C}\right) \mathrm{Ru}\left\{\mathrm{C} \equiv \mathrm{CC}_{6} \mathrm{H}_{4}-4-(E)-\mathrm{CH}=\mathrm{CH}\right\}\right]\right\}_{3} \mathrm{C}_{6} \mathrm{H}_{3}$ $\left[\mathrm{R}=(E)-\mathrm{CH}=\mathrm{CHC}_{6} \mathrm{H}_{4}-4-\mathrm{C} \equiv \mathrm{C}\right.$-trans- $\left.\left[\mathrm{Ru}(\mathrm{C} \equiv \mathrm{CPh})(\text { dppe })_{2}\right] \mathrm{18}\right]$ are reported, together with those of the precursor alkynes $1-\mathrm{RC} \equiv \mathrm{C}$ 3,5- $\mathrm{Et}_{2} \mathrm{C}_{6} \mathrm{H}_{3}\left(\mathrm{R}=\mathrm{SiMe}_{3} 2, \mathrm{H} \mathrm{3}, \mathrm{C}_{6} \mathrm{H}_{4}-4-\mathrm{C} \equiv \mathrm{CSiMe}_{3}\right.$ 5, $\mathrm{C}_{6} \mathrm{H}_{4}-4-$ $\mathrm{C} \equiv \mathrm{CH}$ 6). The identities of $9 \mathrm{c}, 9 \mathrm{~d}, 9 \mathrm{e}, 11 \mathrm{a}$ and trans$\left[\mathrm{Ru}\left\{\mathrm{C} \equiv \mathrm{CC}_{6} \mathrm{H}_{4}-4-(E)-\mathrm{CH}=\mathrm{CHC}_{6} \mathrm{H}_{4}-4-\mathrm{Bu}^{\mathrm{t}}\right\}_{2}(\mathrm{dppe})_{2}\right]$ (12 and 12')
\end{abstract}

[a] Z. Chen, Prof. C. Zhang, Prof. M. P. Cifuentes, Prof. M. G Humphrey

School of Chemical and Material Engineering, Jiangnan University, Wuxi 214122, Jiangsu Province, China.

E-mail: Mark.Humphrey@anu.edu.au

[b] C. J. Jeffery, Dr M. Morshedi, Dr G. J. Moxey, Dr A. Barlow, X. Yang, Dr B. A. Babgi, Dr G. T. Dalton, Dr M. D. Randles, Dr M. K. Smith, Assoc. Prof. M. P. Cifuentes, Prof. M. G. Humphrey

Research School of Chemistry, Australian National University Canberra, ACT 2601, Australia.

[c] Permanent address:

Asst. Prof. B. A. Babgi

Department of Chemistry, Faculty of Science, King Abdulaziz University, P.O. Box 80203, Jeddah 21589, Saudi Arabia

[d] Prof. M. Samoc

Research School of Physics and Engineering,

Australian National University

Canberra, ACT 2601, Australia

Current address:

Advanced Materials Engineering and Modeling Group,

Faculty of Chemistry, Wroclaw University of Technology,

Wroclaw 50-370, Poland were confirmed by single-crystal X-ray diffraction studies. The electrochemical properties of 9a-9e, 11a-11b, 14a-14c, 15a-15c, $16 b, 17 a, 17 b$, and 18 were assessed by cyclic voltammetry; the studies reveal that potentials for the fully/quasi-reversible metalcentered oxidation processes decrease on introduction of solubilizing alkyl substituents and increase on increasing acceptor substituent strength; other structural variations have little impact. UV-vis-NIR spectroscopic studies on these complexes reveal lowest-energy MLCT bands that red-shift on increasing acceptor substituent strength, blue-shift on alkyl incorporation, and gain in intensity on progression from linear to star complexes. Low temperature UV-vis-NIR spectroelectrochemical studies of $14 a-c$ show the appearance of an intense low-energy band at $7400-7900 \mathrm{~cm}^{-1}$ that is red-shifted on $\pi$-system lengthening and alkyl substituent incorporation. The cubic nonlinear optical properties of 9d, 9e, 14a-c, 15a-c, 16b, $\mathbf{1 7 a - b}$ and 18 were assayed by femtosecond Z-scan studies at benchmark wavelengths $(750$ and $800 \mathrm{~nm}$ ) in the near IR, with nonlinearity increasing on nitro incorporation; the values for the $E$-ene-linked dendrimers in these studies are much larger than yne-linked analogues. 9d, 9e, 14a-c and 18 were further examined by broad spectral range femtosecond Z-scan studies; the cruciform complexes have appreciable multiphoton absorption cross-sections, with maximal values close to two- and three-times the wavelength of the linear optical absorption maxima.

\section{Introduction}

The nonlinear optical (NLO) properties of molecular materials have attracted significant interest. ${ }^{[1]}$ While the majority of studies have focused on purely organic molecules, recent comparisons of NLO parameters have shown that organometallics can outperform organics, even when the data are scaled for molecular weights, molecular volumes, numbers of electrons strongly participating in polarization, or even costs of production. ${ }^{[2]}$ The results from these performance comparisons, coupled to the additional functionality inherent in metal complexes (a diversity of 
geometries, performance tuning by co-ligand modification, and the possibility of switching by reversible metal-centered oxidation) have helped drive the continuing interest in organometallics as potential NLO materials, ${ }^{[3]}$ and to maintain them as a genuine alternative to organics.

One structure-NLO property relationship that was developed in early studies of purely organic molecules was the observation of an increase in NLO merit on replacing an yne-linkage in a $\pi$ bridging unit with an $E$-ene linkage, an outcome ascribed to orbital energy mismatch of $p$ orbitals of $s p$-hybridized acetylenic carbons with the $\mathrm{p}$ orbitals of $s p^{2}$-hybridized phenyl carbons; $;{ }^{[4]}$ this effect is presumably in combination with the increased propensity for oligo(phenyleneethynylene) (OPE) units to rotate out of $\pi$-system coplanarity when compared to oligo(phenylenevinylene) (OPV) analogues, reducing efficient $\pi$-delocalization. Metal alkynyl complexes were contemporaneously shown to function as efficient NLO materials, ${ }^{[5]}$ and they continue to provoke interest, but despite the favourable characteristics of $E$-ene-linked species, the vast majority of studies of the NLO properties of metal alkynyl complexes have considered those with an OPE-based rather than OPV-based $\pi$-bridge. We report herein studies directed at addressing this deficiency, including the syntheses of metal alkynyl complexes with OPV-based bridges by a methodology that employs an unusual "chemistry-on-complex" approach at a pendant formyl group, comprehensive evaluation of the electrochemical and spectroscopic properties of the new complexes, structural and spectroelectrochemical studies of selected examples, and an evaluation of their cubic NLO parameters; some of these results have been published in a preliminary form. ${ }^{[6]}$

\section{Results and Discussion}

Previous studies with metal alkynyl complexes have established several outcomes that influenced the research described herein. NLO activity has been shown to increase on proceeding from 14electron complexes to 18-electron complexes, ${ }^{[7]}$ and from $3 d$ metals to $4 \mathrm{~d}$ and $5 \mathrm{~d}$ metals, ${ }^{[8]}$ focusing subsequent research efforts on 18 valence electron ruthenium and osmium alkynyl complexes. While less efficient in an absolute sense than their osmium congeners, ruthenium alkynyl complexes bearing two bidentate diphosphines were found to provide a favourable balance of reactivity and NLO efficiency, ${ }^{\left[{ }^{[0]}\right.}$ so the studies summarized below concentrated on this combination.

Several ruthenium complexes bearing phenylenevinylenecontaining alkynyl ligands have been reported previously, ${ }^{[96,10]}$ but all were prepared by reaction of a (chloro)ruthenium precursor with a pre-formed E-ene-bearing alkyne. To enhance flexibility in the synthesis of such complexes, in the chemistry described below we explored the possibility of using pre-formed (4formylphenylethynyl)ruthenium complexes in Horner-WadsworthEmmons coupling with phosphonate esters. One further point guided the synthetic studies. Alkynyl ligands with multiple phenyleneethynylene units have been shown to afford complexes with significant NLO properties, ${ }^{[9 c, 10 d, 11]}$ but these extended $\pi$ systems are often accompanied by reduced solubility of the complexes in common organic solvents. With this in mind, the syntheses targeted bis(alkynyl)ruthenium complexes containing solubilizing alkyl groups on the terminal aryl ring.

\section{Synthesis of acetylenes}

Two new alkynes bearing solubilizing alkyl groups were targeted for eventual attachment at the periphery of the rutheniumcontaining OPE stars. Thus, 1,3-diethyl-5-\{(4ethynylphenyl)ethynyl\}benzene (5) was prepared via successive Sonogashira coupling ${ }^{[12]} /$ deprotection reactions in four steps (Scheme 1). 2,6-Diethyl-4-iodobenzene (1) was readily obtained via a standard diazotization reaction of 2,6-diethyl-4-iodoaniline ${ }^{[13]}$ with sodium nitrite and fluoroboric acid that afforded 1-iodo-3,5diethylphenyldiazonium fluoroborate, and a subsequent in situ treatment with sodium methoxide in methanol. Sonogashira coupling of 1 with trimethylsilylacetylene using $\mathrm{PdCl}_{2}\left(\mathrm{PPh}_{3}\right)_{2} / \mathrm{Cul}$ as catalysts afforded 3,5-diethyl-1-(trimethylsilylethynyl)benzene (2) in good yield, desilylation of which under basic conditions gave 1,3-diethyl-5-ethynylbenzene (3). A second Sonogashira coupling using 1-iodo-4-(trimethylsilylethynyl)benzene ${ }^{[14]}$ afforded the $\pi$ extended derivative 4-(3,5- $\left.\mathrm{Et}_{2} \mathrm{C}_{6} \mathrm{H}_{3} \mathrm{C} \equiv \mathrm{C}\right) \mathrm{C}_{6} \mathrm{H}_{4} \mathrm{C} \equiv \mathrm{CSiMe}_{3}$ (4), which was then treated with $\mathrm{KOH}$ to give $1-\left(4-\mathrm{HC} \equiv \mathrm{CC}_{6} \mathrm{H}_{4} \mathrm{C} \equiv \mathrm{C}\right)$ $3,5-\mathrm{Et}_{2} \mathrm{C}_{6} \mathrm{H}_{3}$ (5) in excellent yield. The new compounds were obtained as oils and characterized using IR, proton and carbon NMR spectroscopy, and El and high-resolution mass spectrometry. A downfield shift in the NMR signal for the proton para to the iodo/ethynyl is seen on proceeding from $\mathbf{1}$ and $\mathbf{2}$ (6.99 $\mathrm{ppm})$ to $\mathbf{3}$ and 4 (7.06 ppm), a similar downfield shift in the acetylenic proton being seen in proceeding from 3 (3.01 ppm) to $5(3.16 \mathrm{ppm})$. The stilbenylacetylene 8 was obtained from a transhalogenation of $(E)$-1-(4-tert-butylphenyl)-2-(4bromophenyl)ethene ${ }^{[15]}$ with butyl lithium/iodine that gave the iodo derivative (6) (Scheme 1). Compound 6 was then coupled to trimethylsilylacetylene under Sonogashira conditions to give $(E)$ 1-(4-trimethylsilylethynylphenyl)-2-(4-tert-butylphenyl)ethene (7), deprotection using potassium hydroxide giving $(E)$-1-(4-tertbutylphenyl)-2-(4-ethynylphenyl)ethene (8). Compounds 6-8 were characterized by $\mathrm{IR},{ }^{1} \mathrm{H}$ and ${ }^{13} \mathrm{C} \mathrm{NMR}$, and $\mathrm{EI}$ and high resolution ESI mass spectrometry.

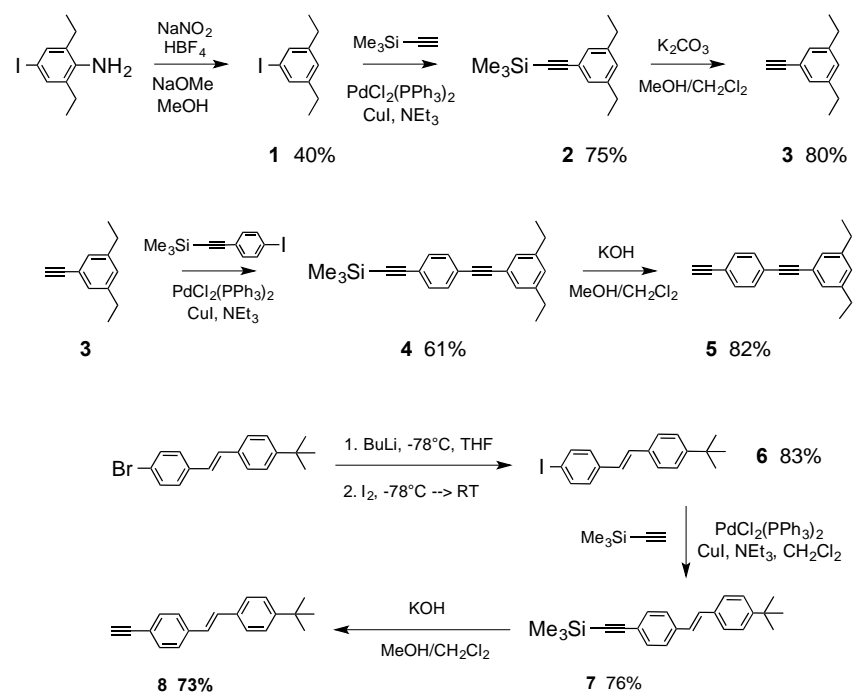

Scheme 1. Syntheses of acetylenes 5 and 8. 


\section{Synthesis of 4-(formylphenyl)alkynyl\}ruthenium complexes} The obvious complexes from which to attempt on-complex Horner-Wadsworth-Emmons coupling, trans- $\left[\mathrm{Ru}\left(\mathrm{C} \equiv \mathrm{CC}_{6} \mathrm{H}_{4}-4\right.\right.$ $\left.\mathrm{CHO}) \mathrm{Cl}\left(\mathrm{L}_{2}\right)_{2}\right]\left(\mathrm{L}_{2}=\right.$ dppe, dppm], have been reported previously ${ }^{[9 \mathrm{c}]}$ and were therefore employed in the present studies, but we also targeted several new ruthenium alkynyl complexes in which the trans-chloro ligand was replaced with alkynyl ligands to enhance stability. The preparation of the 4-(formylphenyl)alkynyl complexes 9a and $\mathbf{9 b}$ employed established procedures for the syntheses of ruthenium alkynyl complexes, with the reactions of trans-[Ru(4-C $\left.\left.\equiv \mathrm{CC}_{6} \mathrm{H}_{4} \mathrm{R}\right) \mathrm{Cl}(\mathrm{dppe})_{2}\right]\left(\mathrm{R}=\mathrm{CHO},{ }^{\left[{ }^{[c]}\right]} \mathrm{NO}_{2}{ }^{[16]}\right)$ with the required terminal acetylene and ammonium or sodium hexafluorophosphate under basic conditions affording ruthenium bis(alkynyl) complexes in acceptable yields (Scheme 2). The reactions can be monitored by NMR spectroscopy, with the phosphorus resonance shifting from around $49 \mathrm{ppm}$ for the mono(alkynyl) complexes to 54.1 (9a) and 53.7 (9b) ppm on formation of the bis(alkynyl) derivatives, and the proton spectrum showing an upfield shift of the aldehyde proton from 9.99 to 9.81 ppm on formation of $9 \mathbf{a}$, and a corresponding resonance appearing at $9.86 \mathrm{ppm}$ for complex $9 \mathrm{~b}$. The order of introduction of the alkynyl ligands is crucial, formation of $9 \mathrm{~b}$ by reaction of 4nitrophenylacetylene ${ }^{[12]} \quad$ with trans-[Ru(4$\left.\left.\mathrm{C} \equiv \mathrm{CC}_{6} \mathrm{H}_{4} \mathrm{CHO}\right) \mathrm{Cl}(\text { dppe })_{2}\right]$ under similar conditions being attempted without success. The bis-(4-formylarylalkynyl) complex 9c was prepared from cis-[RuCl 2 (dppe $\left.)_{2}\right]^{[17]}$ using an excess of acetylene in refluxing dichloromethane, the product being readily identified by the NMR signals at $53.6 \mathrm{ppm}$ for the equivalent phosphorus centers and at $9.87 \mathrm{ppm}$ for the aldehyde protons.

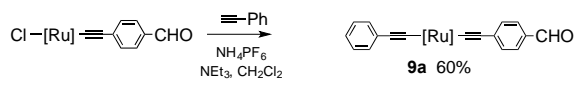

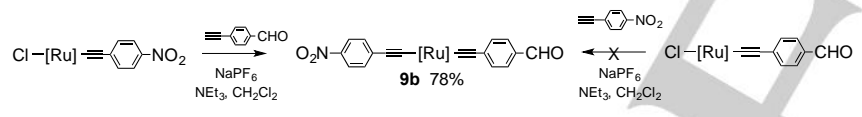

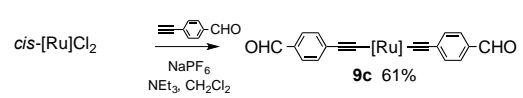

Scheme 2. Syntheses of (4-formylphenyl)ethynylruthenium complexes 9a-9c. $[\mathrm{Ru}]=$ trans $-\left[\mathrm{Ru}\left(\kappa^{2}-\mathrm{dppe}\right)_{2}\right]=$ trans $-\left[\mathrm{Ru}\left(\kappa^{2}-\mathrm{PPh}_{2} \mathrm{CH}_{2} \mathrm{CH}_{2} \mathrm{PPh}_{2}\right)_{2}\right]$.

Ruthenium alkynyl complex formation can frequently be facilitated by the use of the pre-formed five-coordinate $\left[\mathrm{RuCl}(\mathrm{dppe})_{2}\right]^{+}$cation. ${ }^{[18]}$ In the present studies, the fivecoordinate complex cation as its hexafluorophosphate salt $\left[\mathrm{RuCl}(\mathrm{dppe})_{2}\right] \mathrm{PF}_{6}$ (10) was conveniently prepared in over $95 \%$ yield directly from cis-[RuCl $\left.2(\mathrm{dppe})_{2}\right]^{[17]}$ using $\mathrm{NaPF}_{6}$ in dichloromethane. Reaction of $\mathbf{1 0}$ with $\mathbf{5}$ followed by treatment with $\mathrm{NEt}_{3}$ afforded trans-[Ru(C $\left.\left.\equiv \mathrm{CC}_{6} \mathrm{H}_{4}-4-\mathrm{C} \equiv \mathrm{CC}_{6} \mathrm{H}_{3}-3,5-\mathrm{Et}_{2}\right) \mathrm{Cl}(\mathrm{dppe})_{2}\right]$ (11a) in $56 \%$ yield (Scheme 3 ). Formation of the unsymmetrical bis(alkynyl) complex trans- $\left[\mathrm{Ru}\left(\mathrm{C} \equiv \mathrm{CC}_{6} \mathrm{H}_{4}-4-\mathrm{CHO}\right)\left(\mathrm{C} \equiv \mathrm{CC}_{6} \mathrm{H}_{4}-4-\right.\right.$ $\left.\left.\mathrm{C} \equiv \mathrm{CC}_{6} \mathrm{H}_{3}-3,5-\mathrm{Et}_{2}\right)(\mathrm{dppe})_{2}\right](\mathbf{9 d})$ was achieved in $46 \%$ yield after prolonged stirring of 4-ethynylbenzaldehyde ${ }^{[19]}$ with 11a. The transformation from the 5-coordinate cationic complex to the mono- and bis-alkynyl complexes was readily confirmed through the ${ }^{31} \mathrm{P}$ NMR resonances for the dppe ligands, with the two triplets observed for 10 (55.9, $83.7 \mathrm{ppm})$ being replaced by characteristic singlets at 49.2 (11a) and $53.3 \mathrm{ppm}(\mathbf{9 d})$. A similar sequence of reactions using $\left[\mathrm{RuCl}(\mathrm{dppe})_{2}\right] \mathrm{PF}_{6}$ (10) with 8 afforded trans$\left[\mathrm{Ru}\left\{\mathrm{C} \equiv \mathrm{CC}_{6} \mathrm{H}_{4}-4-(E)-\mathrm{CH}=\mathrm{CHC}_{6} \mathrm{H}_{4} \mathrm{Bu}^{\mathrm{t}}-4\right\} \mathrm{Cl}(\text { dppe })_{2}\right]$ (11b), together with trace amounts of the symmetric bis(alkynyl) trans[Ru $\left\{\mathrm{C} \equiv \mathrm{CC}_{6} \mathrm{H}_{4}-4-(E)-\mathrm{CH}=\mathrm{CHC}_{6} \mathrm{H}_{4} \mathrm{Bu}^{\mathrm{t}}-4\right\}_{2}$ (dppe $\left.)_{2}\right]$ (12), and then trans- $\left[\mathrm{Ru}\left(\mathrm{C} \equiv \mathrm{CC}_{6} \mathrm{H}_{4}-4-\mathrm{CHO}\right)\left\{\mathrm{C} \equiv \mathrm{CC}_{6} \mathrm{H}_{4}-4-(E)-\mathrm{CH}=\mathrm{CHC}_{6} \mathrm{H}_{4} \mathrm{Bu}^{\mathrm{t}}-\right.\right.$

$\left.4\}(\text { dppe })_{2}\right](9 e)$ following reaction of $\mathbf{1 1 b}$ with $4-\mathrm{HC} \equiv \mathrm{CC}_{6} \mathrm{H}_{4} \mathrm{CHO}$. All complexes were characterized by IR, ${ }^{1} \mathrm{H}$ and ${ }^{13} \mathrm{C} N M R$ spectroscopy, and El and high resolution ESI mass spectrometry. As expected, the remote alkyl ligand variations have little effect on the ${ }^{1} \mathrm{H}$ NMR aldehyde proton resonance (9.81-9.89 ppm for 9a-e).

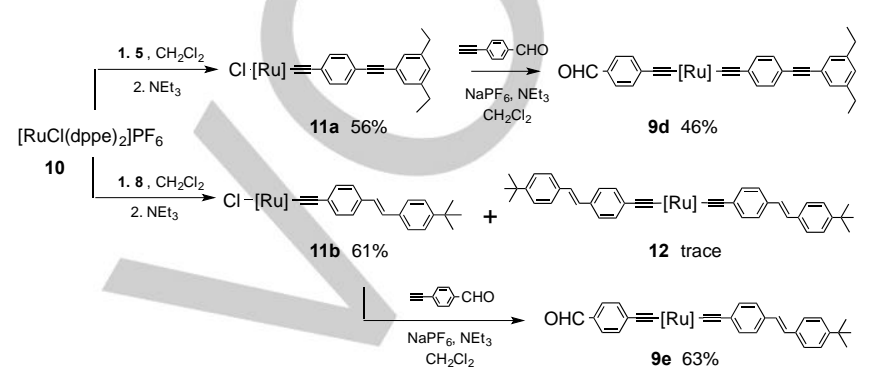

Scheme 3. Syntheses of (4-formylphenylethynyl)ruthenium complexes $9 \mathbf{d}$ and 9e. $[\mathrm{Ru}]=$ trans- $\left[\mathrm{Ru}\left(\kappa^{2}-\mathrm{dppe}\right)_{2}\right]=$ trans $-\left[\mathrm{Ru}\left(\kappa^{2} \square \mathrm{PPh}_{2} \mathrm{CH}_{2} \mathrm{CH}_{2} \mathrm{PPh}_{2}\right)_{2}\right]$

Extension of the classical stereospecific Horner-WadsworthEmmons $\mathrm{C}=\mathrm{C}$ bond formation reaction to metal-containing (4formylphenyl)ethynyl complexes was then explored as a new route to metal-ethynyl-functionalized stilbenes. Our initial attempt examined synthesis of the previously-reported complex trans$\left[\mathrm{Ru}\left\{\mathrm{C} \equiv \mathrm{CC}_{6} \mathrm{H}_{4}-4-(E)-\mathrm{CH}=\mathrm{CHC}_{6} \mathrm{H}_{4}-4-\mathrm{NO}_{2}\right\} \mathrm{Cl}(\mathrm{dppm})_{2}\right]^{[9 \mathrm{~b}]} \quad$ (Scheme 4). trans- $\left[\mathrm{Ru}\left(\mathrm{C} \equiv \mathrm{CC}_{6} \mathrm{H}_{4}-4-\mathrm{CHO}\right) \mathrm{Cl}(\mathrm{dppm})_{2}\right]^{[9 \mathrm{cc}}$ was reacted with sodium hydride and $4-\mathrm{O}_{2} \mathrm{NC}_{6} \mathrm{H}_{4} \mathrm{CH}_{2} \mathrm{P}(\mathrm{O})(\mathrm{OEt})_{2}$ in $\mathrm{THF}$ for $5 \mathrm{~h}$, the latter prepared via an Arbuzov reaction of 1-(bromomethyl)-4nitrobenzene with triethyl phosphite, to give the stereospecifically-coupled (4-\{4-nitrophenyl-(E)ethenyl\}phenyl)ethynyl product (11c) in a greater overall yield than the published procedure [which involves coupling of the preformed $(E)$-1-(4-nitrophenyl)-2-(4-ethynylphenyl)ethene to the ruthenium center]. A similar coupling of the tri-substituted benzylic phosphonate $1,3,5-\mathrm{C}_{6} \mathrm{H}_{3}\left\{\mathrm{CH}_{2} \mathrm{PO}(\mathrm{OEt})_{2}\right\}_{3}{ }^{[20]}$ and excess trans$\left[\mathrm{Ru}\left(\mathrm{C} \equiv \mathrm{CC}_{6} \mathrm{H}_{4}-4-\mathrm{CHO}\right) \mathrm{Cl}(\text { dppe })_{2}\right]$ over $40 \mathrm{~h}$ afforded 13a in acceptable yield, confirming the applicability of this chemistry-oncomplex method for the multi-site incorporation of $E$-ene linkages into ruthenium alkynyl complexes.

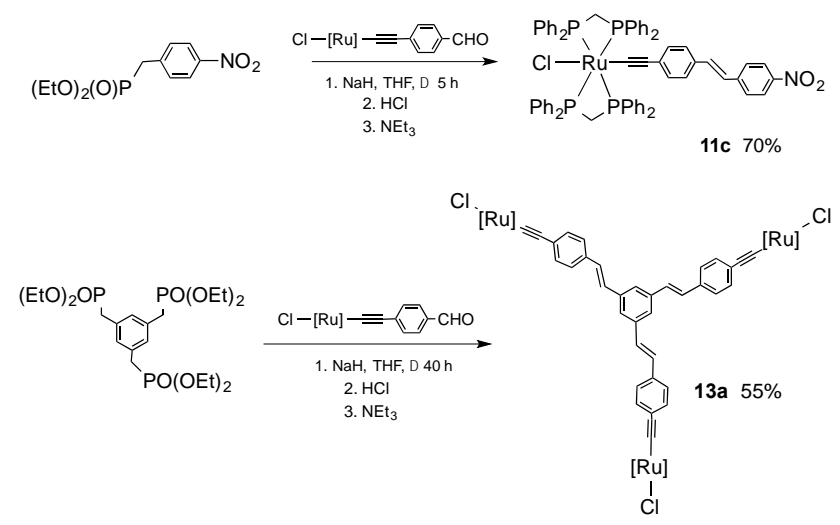


Scheme 4. Syntheses of 11c and 13a by Horner-Wadsworth-Emmons reactions. $[R u]=$ trans $-\left[R u\left(\kappa^{2}-d p p e\right)_{2}\right]$

Having demonstrated this methodology on known complexes, we then extended it to the formation of new E-ene-linkagecontaining ruthenium alkynyl cruciform complexes (Scheme 5). Treatment of $1,2,4,5-\mathrm{C}_{6} \mathrm{H}_{2}\left\{\mathrm{CH}_{2} \mathrm{P}(\mathrm{O})(\mathrm{OEt})_{2}\right\}_{4}{ }^{[20]}$ with the (4formylphenylethynyl)ruthenium complexes $9 a, 9 d$ and $9 e$ and sodium hydride in 1,2-dimethoxyethane for 24-48 $\mathrm{h}$ afforded the tetra-ruthenium star complexes 14a-c in good yields. Formation of the bis(alkynyl) complex environments was confirmed by monitoring the ${ }^{31} \mathrm{P}$ NMR spectra (appearance of resonances at ca. $53 \mathrm{ppm})$.

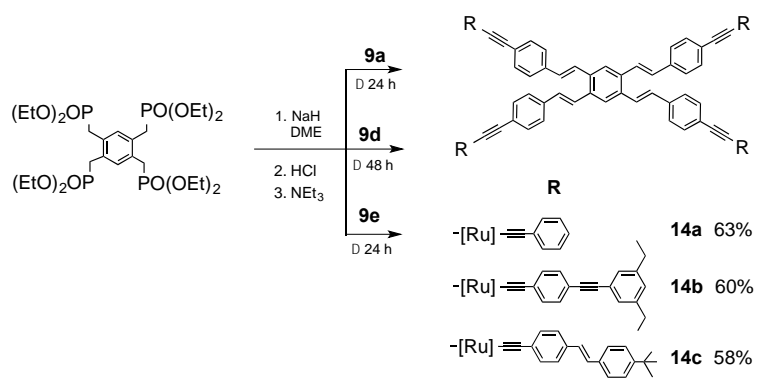

2059, 2072 and $2046 \mathrm{~cm}^{-1}$ for 15a-c, respectively. The alkyny $v(C \equiv C)$ stretching frequency remains unchanged in 15a compared to that of the starting complex; in contrast, the loss of the electron withdrawing aldehyde group in the formation of $\mathbf{1 5 b}$ sees the alkynyl $v(C \equiv C)$ band shift to $2072 \mathrm{~cm}^{-1}$ from $2046 \mathrm{~cm}^{-1}$ in 9a. In 15c, the (4-nitrophenyl)ethynyl ligand affords a band at $2046 \mathrm{~cm}^{-1}$, as is found with $\mathbf{9 b}$. The ESI mass spectrum of $15 \mathrm{a}$ reveals exchange of chloro ligand with solvent $(\mathrm{MeCN})$, a peak being seen at 2270 mass units $\left([\mathrm{M}-\mathrm{Cl}+\mathrm{MeCN}]^{+}\right)$, as well as a peak corresponding to loss of chloride at 2230 mass units ([M $\mathrm{Cl}]^{+}$). The FAB mass spectra of $15 \mathrm{~b}$ and $15 \mathrm{c}$ display molecular ions at 2453 and 2543 mass units, respectively, with 15b fragmenting by loss of the phenylethynyl ligand and iodo group, and $15 \mathrm{c}$ via loss of the nitro substituent.

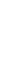


spectrum of $17 \mathbf{b}$ (2350 mass units) with the characteristic loss of a phenylethynyl ligand.

The ethynyl-substituted "wedge" complex $17 \mathrm{~b}$ was then coupled to the previously-reported triruthenium complex $13 \mathrm{a}^{[10 \mathrm{a} \text {, }}$ ${ }_{10 \mathrm{~b}]}$ to form the nonaruthenium dendrimer 18 (Scheme 7). The reaction was monitored by ${ }^{31} \mathrm{P}$ NMR spectroscopy, with the disappearance of the resonance at $50.1 \mathrm{ppm}$ due to the mono(alkynyl) ruthenium environments at $13 \mathbf{a}$ and replacement by a signal at $54.2 \mathrm{ppm}$ due to the resulting bis(alkynyl) ruthenium centers of 18.

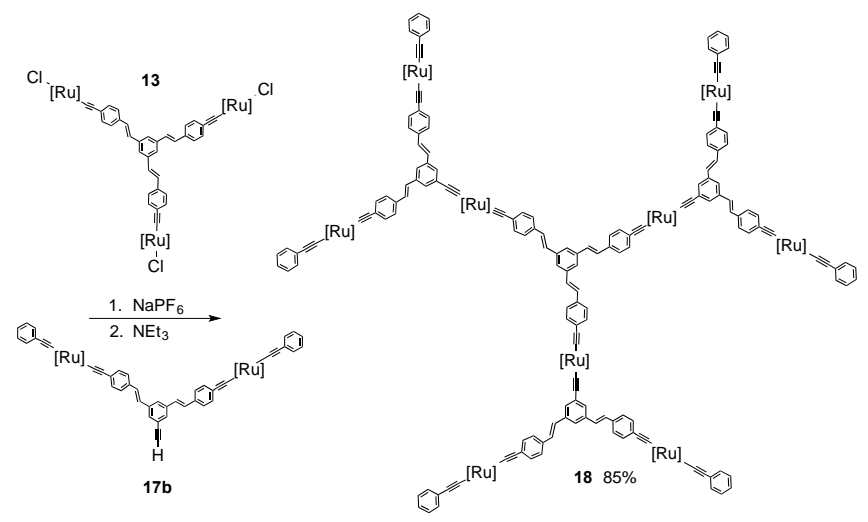

oxidation process at $0.51 \mathrm{~V}$, somewhat lower than that required to oxidize its non-alkylated analogue 11d $(0.55 \mathrm{~V}),{ }^{[22]}$ and presumably due to the slight electron-releasing effect of the alkyl groups. Replacement of the yne linkage furthest from the metal center with an $E$-ene-linked tert-butyl-substituted phenyl group, in proceeding from $11 \mathrm{~d}$ to $11 \mathrm{~b}(0.56 \mathrm{~V})$, has little effect on

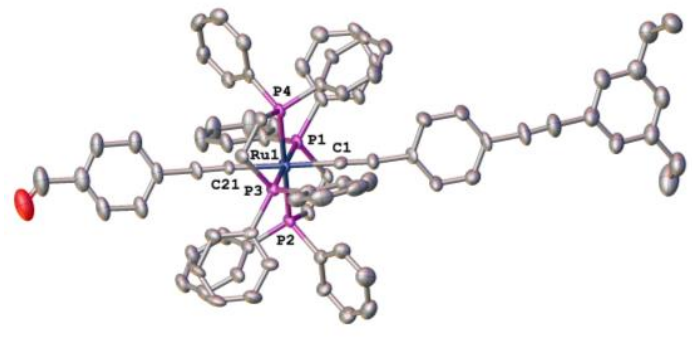

Figure 1. Molecular structure of trans- $\left[\mathrm{Ru}\left(\mathrm{C} \equiv \mathrm{CC}_{6} \mathrm{H}_{4}-4-\mathrm{CHO}\right)\left(\mathrm{C} \equiv \mathrm{CC}_{6} \mathrm{H}_{4}-4\right.\right.$ $\left.\left.\mathrm{C} \equiv \mathrm{CC}_{6} \mathrm{H}_{3}-3,5-\mathrm{Et}_{2}\right)(\mathrm{dppe})_{2}\right](9 \mathrm{~d})$, with thermal ellipsoids set at the $30 \%$ probability level. Hydrogen atoms have been omitted for clarity. Selected bond lengths $(\AA)$ and angles $\left({ }^{\circ}\right)$ : Ru1-C1 2.070(10), Ru1-C21 2.063(9), Ru1-P1 2.373(2), Ru1P2 2.353(2), Ru1-P3 2.372(2), Ru1-P4 2.357(2), C1-Ru1-C21 178.9(4), C1Ru1-P1 80.5(3), C1-Ru1-P2 89.5(2), C1-Ru1-P3 98.7(3), C1-Ru1-P4 90.7(2), C21-Ru1-P1 98.5(3), C21-Ru1-P2 90.8(2), C21-Ru1-P3 82.3(3), C21-Ru1-P4 89.0(2), P1-Ru1-P2 81.63(8), P1-Ru1-P3 179.21(9), P1-Ru1-P4 98.50(8), P2Ru1-P3 98.45(8), P2-Ru1-P4 179.80(10), P3-Ru1-P4 81.43(8).

Scheme 7. Synthesis of the dendritic complex 18. $[R u]=\operatorname{trans}-\left[R u\left(\kappa^{2}-d p p e\right)_{2}\right]=$ trans-[Ru( $\left.\left.\kappa^{\square-}-\mathrm{PPh}_{2} \mathrm{CH}_{2} \mathrm{CH}_{2} \mathrm{PPh}_{2}\right)_{2}\right]$.

\section{Structural studies}

The compositions of compounds 9c, 9d, 9e, 11a, 12' and 12' were confirmed by single-crystal X-ray diffraction studies. The molecular structures are displayed in Figures $\mathrm{S} 1$ (9c), 1 (9d), 2 (9e), S2 (11a), S3 (12'), S4 and S5 (12'), and selected bond length and angle data are collected in the relevant figure captions. The bond lengths and angles about the key $\mathrm{C} / \mathrm{Cl}-\mathrm{Ru}-\mathrm{C}(1)-\mathrm{C}(2)-$ $C(3)$ units in structures $9 \mathrm{c}, \mathbf{9 d}, \mathbf{9 e}$, and 11a are not unusual (see, for example refs [11, 21]), falling within the ranges of the literature precedents for arylalkynylbis(diphosphine)ruthenium complexes; for example, the $\mathrm{Ru}-\mathrm{C}(1)$ vectors for the mono(alkynyl)(chloro)bis(diphosphine)ruthenium complexes [2.037(8) (11a)] and the bis(alkynyl)bis(diphosphine)ruthenium complexes [2.074(4) (9c), 2.070(10), 2.063(9) (9d), 2.065(7), $2.076(6)(9 e)]$ are not unexpected. In contrast, Ru-C(1) parameters for 12' [2.108(5) and 12" [2.149(4)] are both very long possibly an artefact of the substitutional disorder in these specific structural studies.

\section{Cyclic voltammetry studies}

Cyclic voltammetry (CV) data for the complexes prepared in these studies are collected in Table 1. All complexes show an oxidation process between 0.48 and $0.76 \mathrm{~V}$ assigned to the $\mathrm{Ru} \mathrm{u}^{\mathrm{IIIII}}$ oxidation. Ratios for the forward and reverse current peaks range from 0.8 to 1.0 , and peak separations are equivalent to, or in some cases up to $0.03 \mathrm{~V}$ more than, $\Delta \mathrm{E}$ for the ferrocene/ferrocenium internal standard, indicating that these processes are fully or quasireversible. The potentials for the oxidation processes vary in a fairly systematic fashion. 11a, which contains solubilizing ethyl groups on the terminal phenyl ring, shows a fully reversible

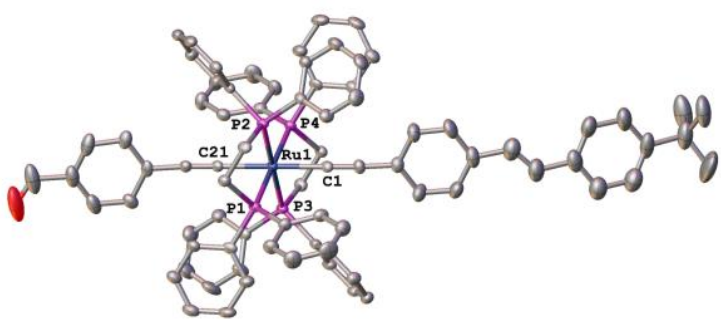

Figure 2. Molecular structure of trans- $\left[\mathrm{Ru}\left(\mathrm{C} \equiv \mathrm{CC}_{6} \mathrm{H}_{4}-4-\mathrm{CHO}\right)\left\{\mathrm{C} \equiv \mathrm{CC}_{6} \mathrm{H}_{4}-4-(E)-\right.\right.$ $\left.\left.\mathrm{CH}=\mathrm{CHC}_{6} \mathrm{H}_{4}-4-\mathrm{Bu}^{\dagger}\right\}(\mathrm{dppe})_{2}\right] \quad(9 \mathrm{e})$, with thermal ellipsoids set at the $30 \%$ probability level. Hydrogen atoms and lattice dichloromethane molecules have been omitted for clarity. Selected bond lengths $(\AA)$ and angles $\left(^{\circ}\right)$ : Ru1-C1 2.065(7), Ru1-C21 2.076(6), Ru1-P1 2.3667(15), Ru1-P2 2.3596(15), Ru1-P3 2.3532(15), Ru1-P4 2.3659(15), C1-Ru1-C21 179.7(3), C1-Ru1-P1 98.28(17), C1-Ru1-P2 91.81(17), C1-Ru1-P3 87.83(17), C1-Ru1-P4 81.30(17), C21-Ru1P1 81.44(17), C21-Ru1-P2 88.33(17), C21-Ru1-P3 92.03(16), C21-Ru1-P4 98.98(17), P1-Ru1-P2 82.56(5), P1-Ru1-P3 97.66(5), P1-Ru1-P4 179.58(6), P2-Ru1-P3 179.60(7), P2-Ru1-P4 97.42(5), P3-Ru1-P4 82.36(5).

the potential for the oxidation process. The similar electronic environment of the metal atom in these related complexes has been noted previously, structural changes occurring remote to the metal center having only minor effects on the potentials for the oxidation processes. ${ }^{[10 \mathrm{~d}]}$ Replacement of the chloro ligand by a 4formylphenylethynyl group, to form the unsymmetrical bis(alkynyl) complexes trans-[Ru(C $\left.\left.\equiv \mathrm{CC}_{6} \mathrm{H}_{4}-4-\mathrm{CHO}\right)\left(\mathrm{C} \equiv \mathrm{CC}_{6} \mathrm{H}_{4}-4-\mathrm{R}\right)(\mathrm{dppe})_{2}\right]$ (9), results in an increase in potentials for the metal-centered oxidation processes. For the (4formylphenylethynyl)(phenylethynyl) examples 9a-9c, $E_{1 / 2}$ increases with increasing electron-withdrawing character of the phenylethynyl substituent, with $\mathrm{R}=\mathrm{H}(\mathbf{9 a}, 0.61 \mathrm{~V})<\mathrm{R}=\mathrm{CHO}(\mathbf{9 c}$, 
$0.72 \mathrm{~V})<\mathrm{R}=\mathrm{NO}_{2}(9 \mathrm{~b}, 0.75 \mathrm{~V})$, as expected. Extension of the $\pi$ bridge of 9a [via a second phenylethynyl unit $\mathrm{R}=\mathrm{C} \equiv \mathrm{CC}_{6} \mathrm{H}_{3}-3,5$ $\mathrm{Et}_{2}$ or a stilbenyl group $\left.\mathrm{R}=(E)-\mathrm{CH}=\mathrm{CHC}_{6} \mathrm{H}_{4}-4-\mathrm{Bu}^{\dagger}\right]$ results in little change in $E_{1 / 2}$.

Potentials of the oxidation processes for the cruciform complexes 1,2,4,5-(trans-[(dppe $)_{2}\left(\mathrm{RC}_{6} \mathrm{H}_{4} \mathrm{C} \equiv \mathrm{C}\right) \mathrm{Ru}\left\{\mathrm{C} \equiv \mathrm{CC}_{6} \mathrm{H}_{4}-4\right.$ $(E)-\mathrm{CH}=\mathrm{CH}\}])_{4} \mathrm{C}_{6} \mathrm{H}_{2}(\mathbf{1 4})$ are all found in the narrow range $0.51-$ $0.55 \mathrm{~V}$, with the diethyl-substituted yne-linked complex $(\mathrm{R}=$ $\left.\mathrm{C} \equiv \mathrm{CC}_{6} \mathrm{H}_{3}-3,5-\mathrm{Et}_{2}, 14 \mathrm{~b}, 0.55 \mathrm{~V}\right)$ again requiring a higher potential than the tert-butyl-substituted ene-linked example $[\mathrm{R}=(E)$ $\left.\mathrm{CH}=\mathrm{CHC}_{6} \mathrm{H}_{4}-4-\mathrm{Bu}^{\mathrm{t}}, 14 \mathrm{c}, 0.51 \mathrm{~V}\right]$. The "wedge" complexes 15-17 are oxidized at comparable potentials, with only a slight variation observed on moving from the 1-iodo-substituted core 15b $(0.53$ $\mathrm{V})$ through the 1-trimethylsilylethynyl- (16b $0.52 \mathrm{~V})$ and ethynyl(17b, $0.56 \mathrm{~V}$ ) analogues, and a slight decrease in the reversibility of the process at each step. Substitution with the electronwithdrawing nitro group (15c, $0.63 \mathrm{~V}$ ) affords a shift to higher potentials, as expected. The chloro-terminated dppm-containing wedge complexes $15 \mathrm{a}(0.62 \mathrm{~V})$ and $17 \mathrm{a}(0.59 \mathrm{~V})$ require a slightly higher potential for metal-centered oxidation than their phenylethynyl-containing analogues $\mathbf{1 5 b}$ and $\mathbf{1 7 b}$.

The general invariance in the potentials for the metal-localized oxidation process in these complexes reflects the similar chemical environment of the metal atom in each case. The single oxidation process observed in the sweep range $(0$ to $1.6 \mathrm{~V})$ is due to the symmetry of the molecules and the lack of interaction between the metal centers. The dendritic complex 18 also shows a single oxidation process $(0.52 \mathrm{~V})$, in agreement with the pseudoequivalent metal environments seen in the ${ }^{31} \mathrm{P}$ NMR data. Complexes containing the nitro group also show an irreversible nitro-centered reduction process at $-1.14 \mathrm{~V}(\mathbf{9 b}),-0.98 \mathrm{~V}(\mathbf{1 1 c})$, and $-1.33 \mathrm{~V}(\mathbf{1 5 c})$.

\section{Linear optical studies}

The UV-vis-NIR spectra for all complexes (Table 1) show characteristic bands at lowest energy [absorption maxima in the range $380-490 \mathrm{~nm}\left(26300-20400 \mathrm{~cm}^{-1}\right)$ ], assigned from DFT calculations on related ruthenium alkynyl complexes as due to metal-to-ligand charge transfer, specifically $R u d_{y z} \rightarrow C_{2} R$ in nature. ${ }^{[23]}$ Nitro-substituted complexes are transparent at frequencies below $22000 \mathrm{~cm}^{-1}$, while all other complexes are transparent below $26000 \mathrm{~cm}^{-1}$. Alkyl introduction at the distal aryl ring of trans- $\left[\mathrm{Ru}\left(\mathrm{C} \equiv \mathrm{CC}_{6} \mathrm{H}_{4}-4-\mathrm{C} \equiv \mathrm{CPh}\right) \mathrm{Cl}(\mathrm{dppe})_{2}\right] \quad\left(\lambda_{\max } 25800\right.$ $\left.\mathrm{cm}^{-1}\right)^{[22]}$ to give 11a $\left(26300 \mathrm{~cm}^{-1},+500 \mathrm{~cm}^{-1}\right)$ results in a slight hypsochromic shift in the MLCT band, whereas replacement of the -yne linkage with an E-ene group and introduction of a tertbutyl group, to give $11 \mathrm{~b}\left(25000 \mathrm{~cm}^{-1},-800 \mathrm{~cm}^{-1}\right)$, produces a bathochromic shift. $\square \square \square$ linear optical spectrum of the nitrosubstituted E-ene-linked complex 11c $\left(20500 \mathrm{~cm}^{-1}\right)$ contains the lowest-energy transition, as expected. ${ }^{[9 c]}$

Substitution of the chloro ligand with a phenylethynyl unit, on

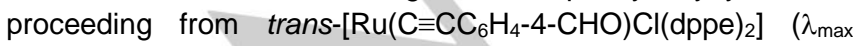
$\left.24200 \mathrm{~cm}^{-1}\right)^{[9 \mathrm{c}]}$ to $\operatorname{trans}-\left[\mathrm{Ru}\left(\mathrm{C} \equiv \mathrm{CC}_{6} \mathrm{H}_{4}-4-\mathrm{CHO}\right)\left(\mathrm{C} \equiv \mathrm{CC}_{6} \mathrm{H}_{4}-4-\right.\right.$ $\mathrm{R})(\text { dppe })_{2}$ ] (9a-c), results in a decrease in the energy of the MLCT, the electron-withdrawing nature of the phenylethynyl substituent determining the size of the shift $\left(\mathrm{R}=\mathrm{H}, 9 \mathrm{a}, 23900 \mathrm{~cm}^{-1},-300 \mathrm{~cm}\right.$ $\left.{ }^{1}\right)<\mathrm{CHO}\left(9 \mathrm{c}, 23500 \mathrm{~cm}^{-1},-700 \mathrm{~cm}^{-1}\right)<\mathrm{R}=\mathrm{NO}_{2}(9 \mathrm{~b}, 21600 \mathrm{~cm}$ $\left.1,-2600 \mathrm{~cm}^{-1}\right)$. Similarly, a red shift is observed on moving from (chloro)ruthenium alkynyl complexes $11 \mathrm{a}$ and $\mathbf{1 1 b}$ to the corresponding (4-formylphenylethynyl) complexes $9 d(24200 \mathrm{~cm}$

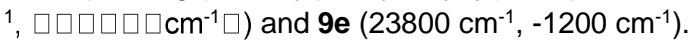

Compared to the monometallic complexes (9 and 11), the cruciform complexes 1,2,4,5-(trans-

$\left.\left[(\text { dppe })_{2}\left(\mathrm{RC}_{6} \mathrm{H}_{4} \mathrm{C} \equiv \mathrm{C}\right) \mathrm{Ru}\left\{\mathrm{C} \equiv \mathrm{CC}_{6} \mathrm{H}_{4}-4-(E)-\mathrm{CH}=\mathrm{CH}\right\}\right]\right)_{4} \mathrm{C}_{6} \mathrm{H}_{2}$ show a significant increase in the extinction coefficient of the MLCT band, an effect noted previously with trisubstituted benzene-cored analogues such as the star complex 1,3,5-\{trans$\left.\left[(\text { dppe })_{2}(\mathrm{PhC} \equiv \mathrm{C}) \mathrm{Ru}\left(\mathrm{C} \equiv \mathrm{CC}_{6} \mathrm{H}_{4}-4-\mathrm{C} \equiv \mathrm{C}\right)\right]\right\}_{3} \mathrm{C}_{6} \mathrm{H}_{3}\left(\mathbf{1 9 b}, \varepsilon 11.6 \times 10^{4}\right.$ $\left.\mathrm{M}^{-1} \mathrm{~cm}^{-1}\right) \cdot{ }^{[24]} \mathrm{In}$ the present studies, the increase in absorbance at $\lambda_{\max }$ for $14 \mathbf{b}\left(\mathrm{R}=\mathrm{C} \equiv \mathrm{CC}_{6} \mathrm{H}_{3}-3,5-\mathrm{Et}_{2}, \varepsilon 20.0 \times 10^{4} \mathrm{M}^{-1} \mathrm{~cm}^{-1}\right)$ and $14 \mathrm{c}$ $\left[\mathrm{R}=(E)-\mathrm{CH}=\mathrm{CHC}_{6} \mathrm{H}_{4}-4-\mathrm{Bu}^{\mathrm{t}}, 21.6 \times 10^{4} \mathrm{M}^{-1} \mathrm{~cm}^{-1}\right]$ is approximately two-fold over that of $14 \mathrm{a}\left(\mathrm{R}=\mathrm{H}, 11.5 \times 10^{4} \mathrm{M}^{-1} \mathrm{~cm}^{-1}\right)$, containing the shorter terminal phenylethynyl ligand, and two-fold over the trimetallic complex 19b. Transition energies are lower for the cruciform star complexes $14 b\left(25300 \mathrm{~cm}^{-1}\right)$ and $14 c\left(22700 \mathrm{~cm}^{-1}\right)$ than for the related mononuclear chloro complexes 11a $(26300$ $\left.\mathrm{cm}^{-1}\right)$ and $11 \mathrm{~b}\left(25000 \mathrm{~cm}^{-1}\right)$ and, again, the ene-linked complex 14b shows the lowest-energy MLCT band. Compared to the trimetallic star complexes, i.e. the yne-linked $19 \mathrm{~b}\left(24300 \mathrm{~cm}^{-1}\right)$ and the E-ene-linked $13 \mathrm{~b}\left(23800 \mathrm{~cm}^{-1}\right),{ }^{[10 \mathrm{~b}]}$ the cruciform star complexes show a higher-energy MLCT band.

Table 1. Cyclic voltammetric and linear optical data. ${ }^{[a]}$

\begin{tabular}{|c|c|c|c|}
\hline $\begin{array}{l}\text { Complex }{ }^{[b]} \\
\mathrm{R}\end{array}$ & & $\begin{array}{l}E_{1 / 2}{ }^{[\mathrm{c}]} \\
{\left[\Delta \mathrm{E},\left(i_{\mathrm{pc}} / i_{\mathrm{pa}}\right]\right.} \\
(\mathrm{V})\end{array}$ & $\begin{array}{l}\lambda \square \square(\mathrm{nm}) \\
\left(\varepsilon \square \square\left(10^{4} \mathrm{M}^{-1} \mathrm{~cm}^{-1}\right)\right.\end{array}$ \\
\hline \multicolumn{4}{|c|}{ trans-[Ru] $\left(\mathrm{C} \equiv \mathrm{CC}_{6} \mathrm{H}_{4}-4-\mathrm{CHO}\right)\left(\mathrm{C} \equiv \mathrm{CC}_{6} \mathrm{H}_{4}-4-\mathrm{R}\right)$} \\
\hline V & $(9 a)$ & $0.61[0.07,0.9]$ & $418(2.3), 313(1.9)$ \\
\hline $\mathrm{NO}_{2}$ & $(9 b)$ & $0.75[0.07,0.8]$ & $463(2.3), 411(\mathrm{sh}, 2.0)$ \\
\hline $\mathrm{CHO}$ & $(9 c)$ & $0.72[0.07,0.8]$ & $426(4.0)$ \\
\hline $\mathrm{C} \equiv \mathrm{CC}_{6} \mathrm{H}_{3}-3,5-\mathrm{Et}_{2}$ & $(9 d)$ & $0.63[0.07,1]$ & $414(5.2)$ \\
\hline$(E)-\mathrm{CH}=\mathrm{CHC}_{6} \mathrm{H}_{4}-4-\mathrm{Bu}^{\mathrm{t}}$ & $(9 e)$ & $0.58[0.07,1]$ & $420(6.1)$ \\
\hline
\end{tabular}

trans-[Ru] $\left(\mathrm{C} \equiv \mathrm{CC}_{6} \mathrm{H}_{4}-4-\mathrm{R}\right) \mathrm{Cl}$

$\mathrm{C} \equiv \mathrm{CC}_{6} \mathrm{H}_{3}-3,5-\mathrm{Et}_{2} \quad$ (11a) $0.51[0.09,1] \quad 380(2.9)$

(E)- $\mathrm{CH}=\mathrm{CHC}_{6} \mathrm{H}_{4}-4-\mathrm{Bu}^{\mathrm{t}} \quad$ (11b) $0.56[0.07,1] \quad 400(4.1)$

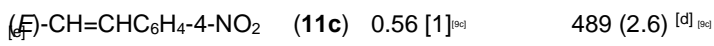

$1,3,5-\left\{\text { trans- }(\mathrm{R})[\mathrm{Ru}]\left(\mathrm{C} \equiv \mathrm{CC}_{6} \mathrm{H}_{4}-(E)-4-\mathrm{CH}=\mathrm{CH}\right)\right\}_{3} \mathrm{C}_{6} \mathrm{H}_{3}{ }^{[10 b]}$

$\begin{array}{llll}\mathrm{Cl} & (\mathbf{1 3 a}) & 0.51[0.9] & 426(8.7)^{[\mathrm{d}]} \\ \mathrm{C} \equiv \mathrm{CPh} & (\mathbf{1 3 b}) & 0.49[1] & 421(13.0)^{[\mathrm{d}]}\end{array}$

1,2,4,5-\{trans- $\left.\left(\mathrm{RC}_{6} \mathrm{H}_{4} \mathrm{C} \equiv \mathrm{C}\right)[\mathrm{Ru}]\left\{\mathrm{C} \equiv \mathrm{CC}_{6} \mathrm{H}_{4}-4-(E)-\mathrm{CH}=\mathrm{CH}\right\}\right\}_{4} \mathrm{C}_{6} \mathrm{H}_{2}$

$\mathrm{H} \quad$ (14a) $0.54[0.11,1] \quad 421(11.5), 325(11.5)$

$\mathrm{C} \equiv \mathrm{CC}_{6} \mathrm{H}_{3}-3,5-\mathrm{Et}_{2} \quad$ (14b) $0.55[0.07,1] \quad 395$ (20.0), $297(14.6)$

$(E)-\mathrm{CH}=\mathrm{CHC}_{6} \mathrm{H}_{4}-4-\mathrm{Bu}^{\mathrm{t}} \quad(14 \mathrm{c}) \quad 0.51[0.09,1] \quad 441(21.6), 315(13.9)$

1-I-3,5-\{trans-(R)[Ru] $\left.\left(\mathrm{C} \equiv \mathrm{CC}_{6} \mathrm{H}_{4}-4-(E)-\mathrm{CH}=\mathrm{CH}\right)\right\}_{2} \mathrm{C}_{6} \mathrm{H}_{3}$

$\mathrm{Cl}^{[\text {e] }} \quad$ (15a) $0.62[0.10,1] \quad 406$

$\mathrm{C} \equiv \mathrm{CPh} \quad$ (15b) $0.53[0.09,1] \quad 425(6.6), 320(6.7)$

$\mathrm{C} \equiv \mathrm{CC}_{6} \mathrm{H}_{4}-4-\mathrm{NO}_{2} \quad$ (15c) $0.63[0.06,1] \quad 481(3.2), 417(3.7), 312(3.9)$

$1-\mathrm{Me}_{3} \mathrm{SiC} \equiv \mathrm{C}-3,5-\left\{\text { trans- }(\mathrm{R})[\mathrm{Ru}]\left(\mathrm{C} \equiv \mathrm{CC}_{6} \mathrm{H}_{4}-4-(E)-\mathrm{CH}=\mathrm{CH}\right)\right\}_{2} \mathrm{C}_{6} \mathrm{H}_{3}$

$\mathrm{Cl}^{[\mathrm{e}]} \quad$ (16a) $411(6.8)$

$\mathrm{C} \equiv \mathrm{CPh} \quad$ (16b) $0.52[0.16,0.9] \quad 421(7.2), 319(7.5)$

$1-\mathrm{HC} \equiv \mathrm{C}-3,5-\left\{\text { trans }-(\mathrm{R})[\mathrm{Ru}]\left(\mathrm{C} \equiv \mathrm{CC}_{6} \mathrm{H}_{4}-4-(E)-\mathrm{CH}=\mathrm{CH}\right)\right\}_{2} \mathrm{C}_{6} \mathrm{H}_{3}$

$\begin{array}{lll}\mathrm{Cl}^{[\mathrm{e}]} & \text { (17a) } 0.59[0.11,0.8] \quad 402,317\end{array}$ 


\begin{tabular}{lccc}
$\mathrm{C} \equiv \mathrm{CPh}$ & $(\mathbf{1 7 b})$ & $0.56[0.15,0.8]$ & 417,320 \\
\hline $1,3,5-\left\{\right.$ trans $\left.\left.-\left(3,5-\mathrm{R}_{2} \mathrm{C}_{6} \mathrm{H}_{3} \mathrm{C} \equiv \mathrm{C}\right)[\mathrm{Ru}]\left\{\mathrm{C} \equiv \mathrm{CC}_{6} \mathrm{H}_{4}-4-(E)-\mathrm{CH}=\mathrm{CH}\right\}\right]\right\}_{3} \mathrm{C}_{6} \mathrm{H}_{3}$ \\
$\left\{(E)-\mathrm{CH}=\mathrm{CHC}_{6} \mathrm{H}_{4}-4-\right.$ & $(\mathbf{1 8})$ & $0.52[0.14,0.8]$ & 417,322 \\
$\mathrm{C} \equiv \mathrm{C}\}[\mathrm{Ru}](\mathrm{C} \equiv \mathrm{CPh})$ & & & \\
\hline
\end{tabular}

[a] Measured as $\mathrm{CH}_{2} \mathrm{Cl}_{2}$ solutions. ${ }^{[b]}[\mathrm{Ru}]=$ trans-[Ru(dppe) $)_{2}$. ${ }^{[c]} \mathrm{Pt}$ disc working-, $\mathrm{Pt}$ wire auxiliary-, and $\mathrm{Ag} / \mathrm{AgCl}$ reference electrodes; ferrocene /ferrocenium redox couple at $0.56 \mathrm{~V}\left(i_{\mathrm{pc}} / i_{\mathrm{pa}} 0.9-1, \Delta \mathrm{E}_{\mathrm{p}}\right.$ 0.07-0.09 $\left.\mathrm{V}\right) .{ }^{[\mathrm{d}]}$ Measured as THF solutions. ${ }^{[e]}[R u]=$ trans- $\left[R u(d p p m)_{2}\right]$.

\section{Spectroelectrochemical studies}

In situ oxidation of metal-containing complexes using an optically transparent thin-layer electrochemical (OTTLE) cell offers a convenient method for accessing spectroscopic data of the oxidized metal complexes, and has been employed widely with ruthenium alkynyl complexes. ${ }^{[10 \mathrm{~d}, 22-23,25]}$ Application of potentials slightly higher than indicated by the cyclic voltammetric data to dichloromethane solutions of the star complexes 14a-c resulted in reversible conversion to the tetracationic (formally $\mathrm{Ru}^{\mathrm{III}} 4$ ) complexes [14a-c] $]^{4+}$; isosbestic points are observed in the transformations in each case (Figures $3, \mathrm{~S} 6$ ), and comparative UV-vis-NIR data have been collected in Table 2. All complexes show the emergence of low-energy NIR absorption bands, assigned to alkynyl-to-Rulll charge transfer, ${ }^{[23 b]}$ with the band for 14b $\left(7600 \mathrm{~cm}^{-1}\right)$, containing the extended $\pi$-delocalizable ligand, occurring at a slightly lower energy than that of $14 a\left(7900 \mathrm{~cm}^{-1}\right)$; the E-ene-linked complex 14c shows the lowest energy band $\left(7300 \mathrm{~cm}^{-1}\right)$. These bands are significantly red-shifted compared to those of the bis(alkynyl) complex trications trans$\left[\mathrm{Ru}(\mathrm{C} \equiv \mathrm{CPh})\left(\mathrm{C} \equiv \mathrm{CC}_{6} \mathrm{H}_{4}-4-\mathrm{C} \equiv \mathrm{CPh}\right)(\mathrm{dppe})_{2}\right]^{+}\left(8400 \mathrm{~cm}^{-1}\right)^{[23 \mathrm{a}]}$ and $\left[1,3,5-\left\{\text { trans }-\left[(\text { dppe })_{2}(\mathrm{PhC} \equiv \mathrm{C}) \mathrm{Ru}\left(\mathrm{C} \equiv \mathrm{CC}_{6} \mathrm{H}_{4}-4-\mathrm{C} \equiv \mathrm{C}\right)\right\}_{3} \mathrm{C}_{6} \mathrm{H}_{3}\right]^{3+}\right.$ $\left(8400 \mathrm{~cm}^{-1}\right) .{ }^{[23 b]}$ This large bathochromic effect is likely due to the E-ene-linked cruciform nature of complexes 14, rather than the increase in the number of metal centers, because the trisubstituted nonaruthenium nonacation [1,3,5-\{trans-[3,5-\{trans[(dppe $)_{2}(\mathrm{PhC} \equiv \mathrm{C}) \mathrm{Ru}\left(\mathrm{C} \equiv \mathrm{CC}_{6} \mathrm{H}_{4}-4\right.$ -

$\left.\left.\left.\mathrm{C} \equiv \mathrm{C})])_{2} \mathrm{C}_{6} \mathrm{H}_{3}(\mathrm{C} \equiv \mathrm{C})(\mathrm{dppe})_{2} \mathrm{Ru}\left(\mathrm{C} \equiv \mathrm{CC}_{6} \mathrm{H}_{4}-4-\mathrm{C} \equiv \mathrm{C}\right)\right]\right\}_{3} \mathrm{C}_{6} \mathrm{H}_{3}\right]^{9+}$ shows the corresponding low energy band at $8400 \mathrm{~cm}^{-1}$ (measured in THF, $\varepsilon$ ca. $\left.8 \times 10^{4} \mathrm{M}^{-1} \mathrm{~cm}^{-1}\right){ }^{[23 \mathrm{~b}]}$ Vibronic progressions evident in the spectra of [14a-c] $]^{4+}$ at ca. $9000 \mathrm{~cm}^{-1}$ can be attributed to $v(\mathrm{C} \equiv \mathrm{C})$, as noted previously in similar complexes. ${ }^{[23 a]}$ The absorption intensities for the lowest-energy bands for the cruciform star complexes [14a-c] ${ }^{4+}$ are uniformly higher than those observed for the related trimetallic star complexes $[\varepsilon$ ca. 12 vs $\left.8\left(\times 10^{4} \mathrm{M}^{-1} \mathrm{~cm}^{-1}\right)\right]$, with the E-ene-linked complex $14 \mathrm{c}$ showing the highest $\varepsilon$.

\section{Cubic hyperpolarizability studies}

The third-order optical nonlinearities of the cruciform, wedge and dendritic molecules 14a-c, 15a-c, 16a, 16b, 17a, 17b and 18 were assessed by the Z-scan technique ${ }^{[26]}$ at a benchmark wavelength of $750 \mathrm{~nm}$, chosen because it corresponds to a region of optical transparency for all of these complexes (reducing the effects of resonance enhancement), and also because of its technological importance (it corresponds to a wavelength region of enhanced transparency of biological materials such as tissue); an NLO performance comparison in this wavelength region is therefore of interest. Measurements were carried out in dichloromethane except for those of $\mathbf{1 5 b}$ and $\mathbf{1 6 b}$, which were measured in THF for solubility reasons; the resultant data are collected in Table 3. At this wavelength, all new complexes exhibit negative nonlinear refraction and positive nonlinear absorption, consistent with the presence of two-photon resonance effects. The real components of the cubic nonlinearities, in particular, are characterized in most cases by large error margins, rendering development of structureproperty relationships problematic. Nevertheless, some comparisons may usefully be made. Focusing on the wedge complexes, replacing the bidentate diphosphine co-ligand dppm by dppe at the ruthenium centers (proceeding from $15 \mathrm{a}$ to $15 \mathrm{~b}$ or $17 a$ to $17 b$ )

Table 2. UV-vis-NIR data for cruciform complexes 1,2,4,5-\{trans$\left.\left[(\text { dppe })_{2}\left(\mathrm{RC}_{6} \mathrm{H}_{4} \mathrm{C} \equiv \mathrm{C}\right) \mathrm{Ru}\left\{\mathrm{C} \equiv \mathrm{CC}_{6} \mathrm{H}_{4}-4-(E)-\mathrm{CH}=\mathrm{CH}\right\}\right]\right)_{4} \mathrm{C}_{6} \mathrm{H}_{2}$ in the resting (14a-c) and tetra-oxidized $\left([\mathbf{1 4 a - c}]^{4+}\right)$ forms. ${ }^{[a]}$

\begin{tabular}{|c|c|c|c|c|}
\hline $\mathrm{R}$ & & $\lambda\left(\mathrm{cm}^{-1}\right)(\varepsilon \square$ & & $\lambda\left(\mathrm{cm}^{-1}\right) \quad\left(\varepsilon \square^{[\mathrm{b}]}\right.$ \\
\hline $\mathrm{H}$ & $14 a$ & $\begin{array}{l}22200(11.5), \\
30700(11.2)\end{array}$ & {$[14 a]^{4+}$} & $\begin{array}{l}7900 \text { (11.6), } 16600 \text { (2.6, sh), } \\
20900 \text { (4.2), } 26000 \text { (7.9), } \\
38300 \text { (19.7) }\end{array}$ \\
\hline $\mathrm{C} \equiv \mathrm{CC}_{6} \mathrm{H}_{3}-3,5-\mathrm{Et}_{2}$ & $14 b$ & $\begin{array}{l}24900(20.0), \\
32100(13.4, \\
\text { sh), } 37000 \\
(15.8, \text { sh })\end{array}$ & {$[14 b]^{4+}$} & $\begin{array}{l}7600(11.9), 16300 \text { (2.3, sh), } \\
20800(7.3), 21900(8.1), \\
25500(11.1), 32100(14.9, \\
\text { sh), } 38000(20.3)\end{array}$ \\
\hline $\begin{array}{l}(E)-\mathrm{CH}=\mathrm{CHC}_{6} \mathrm{H}_{4-} \\
4-\mathrm{Bu}^{\mathrm{t}}\end{array}$ & $14 c$ & $\begin{array}{l}31600(14.4), \\
23700(21.7)\end{array}$ & {$[14 c]^{4+}$} & $\begin{array}{l}7400 \text { (18.1), } 9800 \text { (3.3, sh), } \\
16300 \text { (2.9, sh), } 20000(9.2), \\
28300 \text { (16.3), } 30000 \text { (14.6, } \\
\text { sh), } 38000(19.9)\end{array}$ \\
\hline
\end{tabular}

[a] $\mathrm{CH}_{2} \mathrm{Cl}_{2 \cdot}{ }^{[\mathrm{b}]} \square 10^{4} \mathrm{M}^{-1} \mathrm{~cm}^{-1}$.
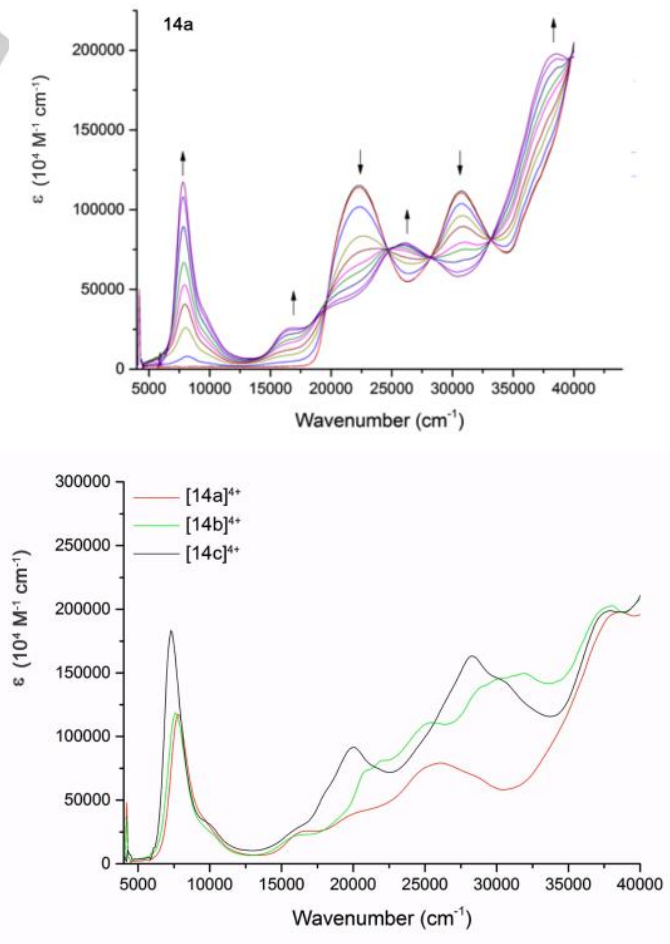

Figure 3. UV-vis-NIR spectral progressions during oxidation of cruciform complex 1,2,4,5-[trans- 
(dppe) $\left.{ }_{2}\left(\mathrm{RC}_{6} \mathrm{H}_{4} \mathrm{C} \equiv \mathrm{C}\right) \mathrm{Ru}\left\{\mathrm{C} \equiv \mathrm{CC}_{6} \mathrm{H}_{4}-4-(E)-\mathrm{CH}=\mathrm{CH}\right\}\right]_{4} \mathrm{C}_{6} \mathrm{H}_{2} \quad(\mathrm{R}=\mathrm{H}$, 14a) (top), and overlay of the spectra for $[14 a-c]^{4+}\left(\mathrm{R}=\mathrm{C} \equiv \mathrm{CC}_{6} \mathrm{H}_{3^{-}}\right.$ 3,5- $\mathrm{Et}_{2}$ (14b), $\mathrm{R}=(E)-\mathrm{CH}=\mathrm{CHC}_{6} \mathrm{H}_{4}-4-\mathrm{Bu}^{\mathrm{t}}$ (14c)) (bottom), in $\mathrm{CH}_{2} \mathrm{Cl}_{2}$.

results in no change in the nonlinearity. The addition of the electron-withdrawing nitro substituent to the arylalkynyl ligand (proceeding from $15 b$ to $15 c$ ) results in a two-fold increase in the nonlinearity. While being mindful of variations resultant upon a difference in measurement wavelength $(750 \mathrm{~nm}$ vs $800 \mathrm{~nm}$, illustrated by data for $9 \mathrm{~d}-\mathrm{e}$ and $\mathbf{1 4 a - c}$ at both wavelengths: Table S2), the nonlinearity $|\gamma|$ varies little between the two classes of wedge complex (with yne- or $E$-ene-containing $\pi$-bridges). As 


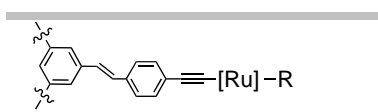

(13)<smiles>[R]c1ccc(C[In](C#Cc2ccc(C=Cc3ccccc3)cc2)c2ccccc2)cc1</smiles>

(14)

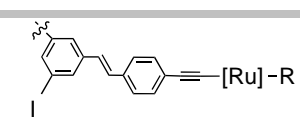

(15)

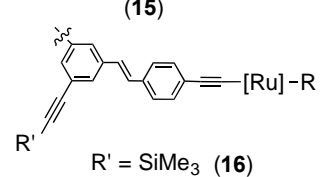

$\begin{array}{ll}\mathrm{R}^{\prime}=\mathrm{H} & (\mathbf{1 7})\end{array}$

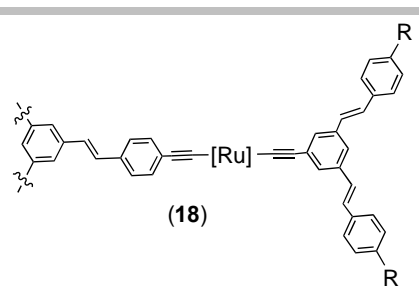

m represents duplication of the Ru-containing unit

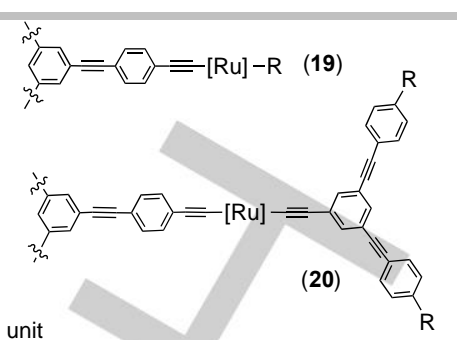

Table 3. Linear optical and cubic nonlinear optical data for selected complexes. ${ }^{a, b}$

\begin{tabular}{llllll}
\hline Complex & $\lambda_{\max }$ & $\gamma_{\text {real }}$ & $\gamma_{\text {imag }}$ & $|\gamma|$ & $\sigma_{2}$ \\
$\mathrm{R}$ & $(\mathrm{nm})$ & $\left(10^{-36} \mathrm{esu}\right)$ & $\left(10^{-36} \mathrm{esu}\right)$ & $\left(10^{-36} \mathrm{esu}\right)$ & $\left(10^{-50} \mathrm{~cm}^{4} \mathrm{~s}\right)$ \\
\hline $1,3,5-(\operatorname{mans})$ &
\end{tabular}

$1,3,5-\left(\right.$ trans $\left.-(\mathrm{R})[\mathrm{Ru}]\left\{\mathrm{C} \equiv \mathrm{CC}_{6} \mathrm{H}_{4}-(E)-4-\mathrm{CH}=\mathrm{CH}\right\}\right){ }_{3} \mathrm{C}_{6} \mathrm{H}_{3}$ measured at $800 \mathrm{~nm}$

\begin{tabular}{llllll}
$\mathrm{Cl}^{[10 \mathrm{~b}]}$ & $(\mathbf{1 3 a})^{[\mathrm{c}]}$ & 426 & $-4600 \pm 2000$ & $4200 \pm 800$ & $6200 \pm 2000$ \\
$\mathrm{C} \equiv \mathrm{CPh}^{[10 \mathrm{~b}]}$ & $(\mathbf{1 3 b})^{[\mathrm{c}]}$ & 421 & $-11200 \pm 3000$ & $8600 \pm 2000$ & $14000 \pm 4000$ \\
\hline
\end{tabular}

1,3,5-(trans-(R) $\left.[\mathrm{Ru}]\left\{\mathrm{C} \equiv \mathrm{CC}_{6} \mathrm{H}_{4}-4-\mathrm{C} \equiv \mathrm{C}\right\}\right)_{3} \mathrm{C}_{6} \mathrm{H}_{3}$ measured at $800 \mathrm{~nm}$

$\begin{array}{lllllr}\mathrm{Cl}{ }^{[27]} & (\mathbf{1 9 a})^{[\mathrm{c}]} & 414 & -330 \pm 100 & 2200 \pm 500 & 2200 \pm 600 \\ \mathrm{C} \equiv \mathrm{CPh}^{[27]} & (\mathbf{1 9 b})^{[\mathrm{c}]} & 411 & -600 \pm 200 & 2900 \pm 500 & 3000 \pm 600\end{array}$

1,2,4,5-(trans $\left.-\left(\mathrm{RC}_{6} \mathrm{H}_{4} \mathrm{C} \equiv \mathrm{C}\right)[\mathrm{Ru}]\left\{\mathrm{C} \equiv \mathrm{CC}_{6} \mathrm{H}_{4}-4-(E)-\mathrm{CH}=\mathrm{CH}\right\}\right){ }_{4} \mathrm{C}_{6} \mathrm{H}_{2}$

\begin{tabular}{|c|c|c|c|c|c|c|}
\hline $\mathrm{H}$ & $(14 a)$ & 440 & $-38200 \pm 7790$ & $7370 \pm 3100$ & $38900 \pm 8380$ & $2090 \pm 880$ \\
\hline $\mathrm{C} \equiv \mathrm{CC}_{6} \mathrm{H}_{3} \mathrm{Et}_{2}-3,5$ & $(14 b)$ & 393 & $-36000 \pm 10600$ & $14200 \pm 5800$ & $38700 \pm 12000$ & $4020 \pm 1640$ \\
\hline$(E)-\mathrm{CH}=\mathrm{CHC}_{6} \mathrm{H}_{4} \mathrm{Bu}^{\mathrm{t}}-4$ & $(14 c)$ & 415 & $-36000 \pm 10600$ & $14200 \pm 5800$ & $38700 \pm 12000$ & $4020 \pm 1640$ \\
\hline
\end{tabular}

1-I-3,5-(trans-(R)[Ru] $\left.\left\{\mathrm{C} \equiv \mathrm{CC}_{6} \mathrm{H}_{4}-4-(E)-\mathrm{CH}=\mathrm{CH}\right\}\right)_{2} \mathrm{C}_{6} \mathrm{H}_{3}$

$\begin{array}{llllll}\mathrm{Cl}[\mathrm{d}] & \mathbf{( 1 5 a )} & 406 & -1800 \pm 490 & 300 \pm 70 & 1800 \pm 500 \\ \mathrm{C} \equiv \mathrm{CPh} & (\mathbf{1 5 b}){ }^{[\mathrm{c}]} & 425 & -2200 \pm 260^{[\mathrm{e}]} & 220 \pm 60^{[\mathrm{e}]} & 2200 \pm 260[\mathrm{~d}] \\ \mathrm{C} \equiv \mathrm{CC}_{6} \mathrm{H}_{4} \mathrm{NO}_{2}-4 & (\mathbf{1 5 c}) & 481 & -4200 \pm 1,500 & 1500 \pm 420 & 4500 \pm 1600\end{array}$

$1-\mathrm{Me}_{3} \mathrm{SiC} \equiv \mathrm{C}-3,5-\left(\text { trans }-(\mathrm{R})[\mathrm{Ru}]\left\{\mathrm{C} \equiv \mathrm{CC}_{6} \mathrm{H}_{4}-4-(E)-\mathrm{CH}=\mathrm{CH}\right\}\right)_{2} \mathrm{C}_{6} \mathrm{H}_{3}$

\begin{tabular}{llllll}
$\mathrm{Cl}{ }^{[\mathrm{d}]}$ & $\mathbf{( 1 6 a )}$ & 411 & $-510 \pm 500$ & $4700 \pm 1500$ & $4700 \pm 2000$ \\
$\mathrm{C} \equiv \mathrm{CPh}$ & $(\mathbf{1 6 b})^{[\mathrm{c}]}$ & 421 & $-2100 \pm 140$ & $410 \pm 60$ & $2100 \pm 150$ \\
\hline
\end{tabular}

$1-\mathrm{HC} \equiv \mathrm{C}-3,5-\left(\text { trans }-(\mathrm{R})[\mathrm{Ru}]\left\{\mathrm{C} \equiv \mathrm{CC}_{6} \mathrm{H}_{4}-4-(E)-\mathrm{CH}=\mathrm{CH}\right\}\right)_{2} \mathrm{C}_{6} \mathrm{H}_{3}$

$\begin{array}{llllll}\mathrm{Cl}[\mathrm{d}] & (\mathbf{1 7 a}) & 402 & -1900 \pm 230 & 140 \pm 20 & 1900 \pm 230 \\ \mathrm{C} \equiv \mathrm{CPh} & (\mathbf{1 7 b}) & 417 & -1900 \pm 260 & 300 \pm 40 & 1900 \pm 260\end{array}$

$1,3,5-\left(\text { trans }-\left(3,5-\mathrm{R}_{2} \mathrm{C}_{6} \mathrm{H}_{3} \mathrm{C} \equiv \mathrm{C}\right)[\mathrm{Ru}]\left\{\mathrm{C} \equiv \mathrm{CC}_{6} \mathrm{H}_{4}-4-(E)-\mathrm{CH}=\mathrm{CH}\right\}\right)_{3} \mathrm{C}_{6} \mathrm{H}_{3}$
(E) $-\mathrm{CH}=\mathrm{CHC}_{6} \mathrm{H}_{4}-4-$
(18) 417
$-6700 \pm 770$
$1300 \pm 130$
$6800 \pm 780$

$\mathrm{C} \equiv \mathrm{C})[\mathrm{Ru}](\mathrm{C} \equiv \mathrm{CPh})$

$1,3,5-\left\{\text { trans }-\left(3,5-\mathrm{R}_{2} \mathrm{C}_{6} \mathrm{H}_{3} \mathrm{C} \equiv \mathrm{C}\right)[\mathrm{Ru}]\left(\mathrm{C} \equiv \mathrm{CC}_{6} \mathrm{H}_{4}-4-\mathrm{C} \equiv \mathrm{C}\right)\right\}_{3} \mathrm{C}_{6} \mathrm{H}_{3}{ }^{[27]}$ measured at $800 \mathrm{~nm}$

$(\mathrm{C} \equiv \mathrm{C})[\mathrm{Ru}](\mathrm{C} \equiv \mathrm{CPh}) \quad(\mathbf{2 0})^{[\mathrm{c}]} \quad 402 \quad-5050 \pm 500 \quad 20100 \pm 2000 \quad 20700 \pm 2000 \quad 4800 \pm 500$

[a] Measurements are referenced to the nonlinear refractive index of silica $n_{2}=3 \times 10^{-16} \mathrm{~cm}^{2} \mathrm{~W}^{-1}$. ${ }^{[b]}$ Complexes measured as $\mathrm{CH}_{2} \mathrm{Cl}_{2}$ solutions and at $750 \mathrm{~nm}$ with $[R u]=$ trans-Ru(dppe) $)_{2}$ unless otherwise specified. ${ }^{[c]}$ Measured as THF solutions. ${ }^{[d]}[R u]=$ trans-Ru(dppm) 2 . 
expected for a relatively subtle change at these large molecules, replacing the iodo substituent with either $\mathrm{C} \equiv \mathrm{CSiMe}_{3}$ or $\mathrm{C} \equiv \mathrm{CH}$ does not significantly affect the nonlinearity $(\mathbf{1 5 b}, \mathbf{1 6 b}, \mathbf{1 7 b})$.

Focusing on the dendrimer complexes, proceeding from the zero-generation yne-linked dendrimers $(19 a, 19 b)$ to the comparable E-ene-linked dendrimers $(13 \mathbf{a}, \mathbf{1 3} \mathbf{b})$ results in a marked increase in the nonlinear response. Although increasing the dendrimer generation, in moving from the zero- (19b) to firstgeneration yne-linked dendrimer $(20)$ results in an approximately ten-fold increase in the nonlinearity, this effect is not seen with $E$ ene-linked dendrimers (proceeding from 13b to 18); in fact the nonlinearity decreases by a factor of two. This may be caused by an increasing loss of coplanarity in moving to $\mathbf{1 8}$, or by the wavelength dependence of the response (although the near coincidence of the linear optical absorption maxima suggests that this may not be a critical factor). Finally, the observed nonlinearities of the cruciform complexes at this benchmark wavelength are the largest from the present study. The overall $|\gamma|$ values are dominated by very large $\gamma_{\text {real }}$ contributions - while the energies of transitions for complexes across the present study are similar, it is noteworthy that the extinction coefficients for the lowest energy one-photon absorption bands for 14a-c are much larger than those for the other complexes, and this may suggest significantly enhanced resonance effects.

The impressive NLO coefficients at the aforementioned benchmark wavelengths prompted a more detailed study of selected examples over the relatively broad spectral range 500$1600 \mathrm{~nm}$, with a particular focus on the cruciform star complexes. Representative $\sigma_{2}$ and $\gamma$ spectral dependences (those for 14a) are displayed in Figure 4, the remainder being shown in Figures S7 (9d), S8 (9e), S9 (14b), S10 (14c), and S11 (18), while maximal data are collected in Table S3. All complexes studied are multiphoton absorbers, showing positive imaginary components of the third-order nonlinearity in the range $500-1500 \mathrm{~nm}$. These complexes exhibit large apparent two-photon absorption (2PA) cross-sections at short wavelengths $(500 / 520 \mathrm{~nm})$, which is probably a combination of 2PA and excited-state absorption/reverse saturable absorption (ESA/RSA) due to the measurements being undertaken at the low-energy end of the linear absorption; the reported 2PA values at such wavelengths should therefore be considered with caution. The monometallic compounds (9d and 9e) have a common 2PA peak at $640 \mathrm{~nm}$, the ethenyl-linked $9 \mathrm{e}$ having a larger cross-section. The 2PA maxima are at lower energies for $9 \mathrm{e}$ than $\mathbf{9 d}$ in the range $740-900$ $\mathrm{nm}$, consistent with the lower-energy MLCT in the linear absorption spectrum (to which these 2PA maxima are correlated).

The monometallic compounds, $9 \mathbf{d}$ and $9 \mathbf{e}$, are "building blocks" for the formation of $\mathbf{1 4 b}$ and $\mathbf{1 4 c}$, respectively. Addition of the monomer $9 \mathrm{~d} / \mathbf{9 e}$ to the core to afford $\mathbf{1 4 b / 1 4 c}$ appreciably changes the 2PA spectrum; 2PA maxima are shifted to lower energy by around $20-40 \mathrm{~nm}$, and the maximal values of the crosssection at these wavelengths increase seven- to ten-fold. A strong response at around $1150 \mathrm{~nm}$ also appears, which correlates closely with three times the wavelength of the lowest energy linear absorption band, and probably arises from three-photon absorption. This low-energy nonlinear absorption band is at a shorter wavelength than that observed for the 1,3,5-substituted analogue $18(1300 \mathrm{~nm})$, possibly a consequence of changing the core geometry of these star complexes. Attempts at 'tuning' the NLO properties with alteration of the capping groups appear to give negligible changes in the values of the NLO parameters (while being mindful of the associated errors), although the longer-peripheral $\pi$-system-containing $14 \mathrm{~b}$ and $\mathbf{1 4 c}$ have stronger nonlinear absorptive properties at the longer wavelength maxima than does the phenyl-capped complex 14a. This behavior may indicate that the NLO properties are overwhelmingly influenced by the core geometry rather than the peripheral substitution.
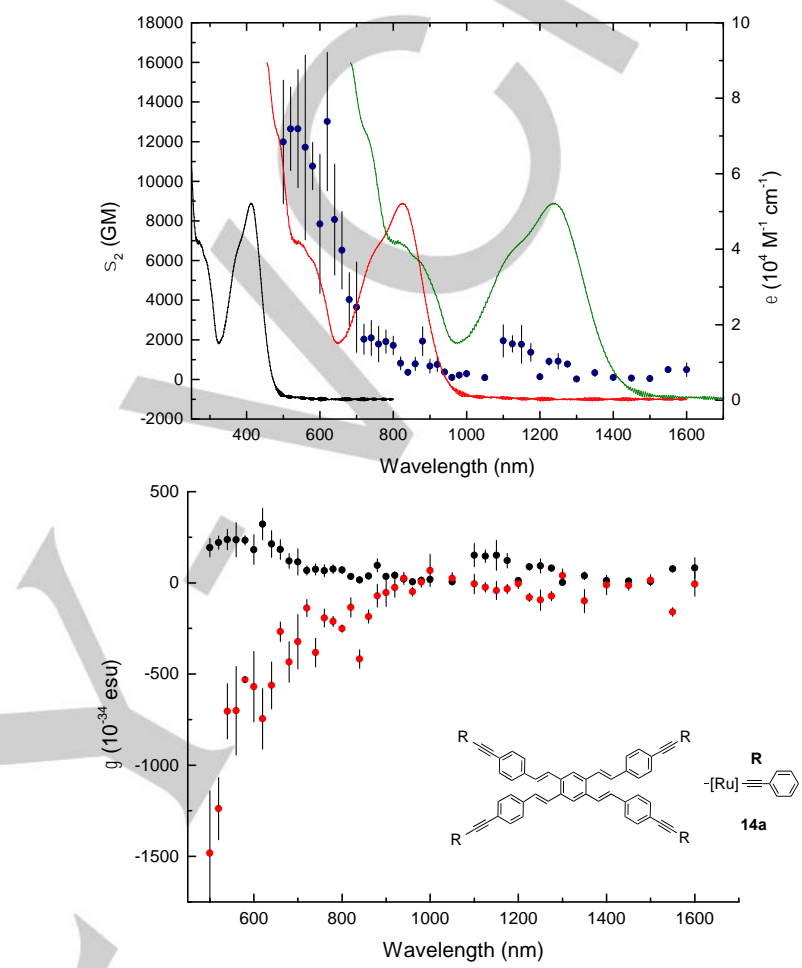

Figure 4. (top) Plot of $\sigma_{2}$ (b/ue) for 14a overlaid on the UVvisible spectrum (black), and including plots of the UV-visible spectrum at twice (red) and three-times (green) the wavelength. (bottom) The real (red) and imaginary (black) parts of the thirdorder hyperpolarizability of $\mathbf{1 4 a}$.

\section{Conclusions}

The studies described herein have demonstrated useful outcomes from both the synthetic and materials perspectives. The "chemistry-on-complex" stereospecific formation of E-configured stilbene groups by Horner-Wadsworth-Emmons coupling of metal-ethynyl-functionalized benzaldehydes employed in this work has been shown to afford facile access to a range of "star" complexes, with both 1,3,5-trisubstituted arene and 1,2,4,5tetrasubstituted arene (cruciform) geometries. Formyl substituents on arenes are ubiquitous in organic chemistry and undergo a broad range of reactions and consequent functionalization; the scope for analogous "chemistry-on-complex" transformation of metal-ethynyl-derivatized benzaldehydes remains to be explored, but the present studies have provided a glimpse of the potential.

Access to the range of ruthenium alkynyl-functionalized oligo(phenylenevinylene) stars, which the present studies has afforded, has permitted both an internal comparison of their 
properties across the complexes described here, and an external comparison to those of the extant ruthenium alkynylfunctionalized oligo(phenyleneethynylene) analogues, allowing several structure-property outcomes to be highlighted. Alkyl substituents were employed in the present work to ensure sufficient solubility, but their electron-releasing nature is reflected in increased ease of oxidation and a blue-shift in optical absorption maximum. Incorporation of nitro substituents increases the potentials of the metal-centered oxidation processes, red-shifts the optical absorption maximum, and increases the maximal value of the cubic NLO properties. Progression from 1,3,5-trisubstituted arene core to 1,2,4,5tetrasubstituted arene (cruciform) core results in a substantial increase in linear optical absorption maximum extinction coefficient, a decrease in energy of the LMCT band in the spectrum of the oxidized form, and a significant increase in maximal values of the nonlinear absorption. Finally, replacing the yne-linkages from the extant complexes with the $E$-ene linkages in the present work results in a blue-shift in optical absorption maximum, a red-shift in the LMCT band in the spectrum of the oxidized form, and an increase in nonlinear absorption crosssection; thus, the OPV-based star complexes from the present study exhibit enhanced nonlinearities with a slight gain in optical transparency.

\section{Acknowledgements}

We thank the Australian Research Council (ARC) for financial support. M.D.R. was the recipient of an Australian Postgraduate Award, X.Y. is the recipient of a China Scholarship Council ANU Postgraduate Scholarship, M.P.C. thanks the ARC for Australian Research Fellowships, and M.G.H. thanks the ARC for Australian Professorial Fellowships. M.S. acknowledges the NCN grant DEC-2013/10/A/ST4/00114.

\section{Keywords}

Organometallic chemistry • Molecular electrochemistry • Nonlinear optics $•$ Transition metals

\section{Supporting Information}

Complete details of the syntheses and characterization of compounds 1-5, 7, and 8, and complexes 9a-9e, 10, 11a-11c, 13a, 14a-14c, 15a-15c, 16a, 16b, 17a, 17b, and 18, crystallographic studies of $9 c-9 e, 11 a, 12$ ', and 12", electrochemical studies of all new complexes, spectroelectrochemical studies of $14 a-14 c$, single-wavelength nonlinear optical studies of 15a-15c, 16b, 17a, $17 \mathrm{~b}$, and 18, and broad spectral range nonlinear optical studies of $9 \mathrm{~d}, 9 \mathrm{e}, \mathbf{1 4 a - 1 4 c}$, and 18 are reported in the Supporting Information, available on the WWW under http://dx.doi.org/10.1002/cplu.2015xxxxx.

\section{References}

[1] a) W. W. Boyd, Nonlinear Optics, 3rd ed., Academic Press, Amsterdam, 2008; b) R. L. Sutherland, D. G. McLean, K. Sean,
Handbook of Nonlinear Optics, 2nd ed, Marcel Dekker, New York, 2003.

[2] T. Schwich, M. P. Cifuentes, P. A. Gugger, M. Samoc, M. G. Humphrey, Adv. Mater. 2011, 23, 1433-1435.

[3] a) J. P. L. Morrall, G. T. Dalton, M. G. Humphrey, M. Samoc, Adv. Organomet. Chem. 2007, 55, 61-136; b) M. E. Thompson, P. E. Djurovich, S. Barlow, S. Marder, in Comprehensive Organometallic Chemistry III, Vol. 12 (Eds.: R. H. Crabtree, D. M. P. Mingos), Elsevier, Oxford, 2007, pp. 101-194; c) M. G. Humphrey, T. Schwich, P. J. West, M. P. Cifuentes, M. Samoc in Comprehensive Inorganic Chemistry II, Vol. 8 (Eds.: J. Reedijk, K. Poeppelmeier), Elsevier, Oxford, UK, 2012, pp. 781835.

[4] L.-T. Cheng, W. Tam, S. R. Marder, A. E. Stiegman, G. Rikken, C. W. Spangler, J. Phys. Chem. 1991, 95, 10643-10652.

[5] a) P. L. Porter, S. Guha, K. Kang, C. C. Frazier, Polymer 1991 32, 1756-1760; b) W. J. Blau, H. J. Byrne, D. J. Cardin, A. P. Davey, J. Mater. Chem. 1991, 1, 245-249; c) T. B. Marder, G. Lesley, Z. Yuan, H. B. Fyfe, P. Chow, G. Stringer, I. R. Jobe, N. J. Taylor, I. D. Williams, S. K. Kurtz, in Materials for Nonlinear Optics: Chemical Perspectives (Eds.: S. R. Marder, J. E. Sohn, G. D. Stucky), ACS, Washington DC, 1991, pp. 605-615; d) L. K. Myers, C. Langhoff, M. E. Thompson, J. Am. Chem. Soc. 1992, 114, 7560-7561; e) I. R. Whittall, M. G. Humphrey, M. Samoc, J. Swiatkiewicz, B. Luther-Davies, Organometallics 1995, 14, 5493-5495; f) Z. Yuan, N. J. Taylor, R Ramacharandran, T. B. Marder, Appl. Organomet. Chem. 1996, $10,305-316$; g) S. Houbrechts, K. Clays, A. Persoons, V Cadierno, P. M. Gamasa, J. Gimeno, Organometallics 1996, 15, 5266-5268.

[6] C. J. Jeffery, M. P. Cifuentes, G. T. Dalton, T. C. Corkery, M. D. Randles, A. C. Willis, M. Samoc, M. G. Humphrey, Macromol. Rapid Commun. 2010, 31, 846-849.

[7] a) I. R. Whittall, M. G. Humphrey, S. Houbrechts, A. Persoons, D. C. R. Hockless, Organometallics 1996, 15, 5738; b) I. R Whittall, M. P. Cifuentes, M. G. Humphrey, B. Luther-Davies, M Samoc, S. Houbrechts, A. Persoons, G. A. Heath, D. Bogsanyi, Organometallics 1997, 16, 2631-2637.

[8] a) A. M. McDonagh, M. P. Cifuentes, M. G. Humphrey, S. Houbrechts, J. Maes, A. Persoons, M. Samoc, B. Luther-Davies, J. Organomet. Chem. 2000, 610, 71-79; b) C. E. Powell, M. P. Cifuentes, A. M. McDonagh, S. Hurst, N. T. Lucas, C. D. Delfs, R. Stranger, M. G. Humphrey, S. Houbrechts, I. Asselberghs, A Persoons, D. C. R. Hockless, Inorg. Chim. Acta 2003, 352, 918.

[9] a) A. M. McDonagh, I. R. Whittall, M. G. Humphrey, D. C. R Hockless, B. W. Skelton, A. H. White, J. Organomet. Chem 1996, 523, 33-40; b) A. M. McDonagh, I. R. Whittall, M. G. Humphrey, B. W. Skelton, A. H. White, J. Organomet. Chem 1996, 519, 229-235; c) S. Hurst, M. P. Cifuentes, J. P. L. Morrall, N. T. Lucas, I. R. Whittall, M. G. Humphrey, I. Asselberghs, A. Persoons, M. Samoc, B. Luther-Davies, A. C. Willis, Organometallics 2001, 20, 4664 - 4675.

[10] a) S. K. Hurst, N. T. Lucas, M. G. Humphrey, T. Isoshima, K Wostyn, I. Asselberghs, K. Clays, A. Persoons, M. Samoc, B. Luther-Davies, Inorg. Chim. Acta 2003, 350, 62-76; b) S. K. Hurst, M. G. Humphrey, T. Isoshima, K. Wostyn, I. Asselberghs, K. Clays, A. Persoons, M. Samoc, B. Luther-Davies, Organometallics 2002, 21, 2024-2026; c) I. R. Whittall, M. G. Humphrey, M. Samoc, B. Luther-Davies., Angew. Chem., Int Ed. Engl. 1997, 36, 370-371; d) L. Rigamonti, B. Babgi, M. P. Cifuentes, R. L. Roberts, S. Petrie, R. Stranger, S. Righetto, A. Teshome, I. Asselbergh, K. Clays, M. G. Humphrey, Inorg Chem. 2009, 48, 3562-3572; e) I. R. Whittall, M. G. Humphrey, A. Persoons, S. Houbrechts, Organometallics 1996, 15, 1935 1941.

[11] B. Babgi, L. Rigamonti, M. P. Cifuentes, T. C. Corkery, M. D. Randles, T. Schwich, S. Petrie, R. Stranger, A. Teshome, I. Asselbergh, K. Clays, M. Samoc, M. G. Humphrey, J. Am. Chem. Soc. 2009, 131, 10293-10307.

[12] S. Takahashi, Y. Kuroyama, K. Sonogashira, N. Hagihara, Synthesis 1980, 627-630. 
[13] I. Ehlers, P. Maity, J. Aubé, B. König, Eur. J. Org. Chem. 2011, 2474-2490.

[14] O. Lavastre, S. Cabioch, P. H. Dixneuf, J. Vohlidal, Tetrahedron 1997, 53, 7595-7604.

[15] S. Barlow, C. Risko, S.-J. Chung, N. M. Tucker, V. Coropceanu, S. C. Jones, Z. Levi, J.-L. Brédas, S. R. Marder, J. Am. Chem Soc. 2005, 127, 16900-16911.

[16] D. Touchard, P. Haquette, S. Guesmi, L. L. Pichon, A. Daridor, L. Toupet, P. H. Dixneuf, Organometallics 1997, 16, 3640-3648.

[17] K. A. Green, M. P. Cifuentes, T. C. Corkery, M. Samoc, M. G. Humphrey, Angew. Chem. Int. Ed. 2009, 48, 7867-7870.

[18] N. Gauthier, C. Olivier, S. Rigaut, D. Touchard, T. Roisnel, M. G. Humphrey, F. Paul, Organometallics 2008, 27, 1063-1072.

[19] W. B. Austin, N. Bilow, W. J. Kelleghan, K. S. Y. Lau, J. Org. Chem. 1981, 46, 2280-2286.

[20] A. Winter, C. Friebe, M. D. Hager, U. S. Schubert, Eur. J. Org. Chem. 2009, $801-809$.

[21] a) A. M. McDonagh, M. P. Cifuentes, I. R. Whittall, M. G Humphrey, M. Samoc, B. Luther-Davies, D. C. R. Hockless, J. Organomet. Chem. 1996, 526, 99-103; b) S. K. Hurst, M. G. Humphrey, J. P. Morrall, M. P. Cifuentes, A. Samoc, B. LutherDavies, A. C. Willis, J. Organomet. Chem. 2003, 670, 56 - 65; c) Z. Li, A. M. Beatty, T. P. Fehlner, Inorg Chem 2003, 5707 5714; d) Q. Ge, T. S. A. Hor, Dalton Trans. 2008, 2929-2936 e) G. A. Koutsantonis, G. I. Jenkins, P. A. Schauer, B. Szczepaniak, B. W. Skelton, C. Tan, A. H. White, Organometallics 2009, 28, 2195-2205; f) C. Olivier, S. De Sousa, L. Ducasse, B. Kauffmann, T. Toupance, Chem. Eur. J. 2014, 20, 7017-7024.

[22] M. P. Cifuentes, C. E. Powell, M. G. Humphrey, G. A. Heath, M. Samoc, B. Luther-Davies, J. Phys. Chem. A 2001, 105, 9625 9627.

[23] a) C. E. Powell, M. P. Cifuentes, J. P. L. Morrall, R. Stranger, M. G. Humphrey, M. Samoc, B. Luther-Davies, G. A. Heath, J. Am Chem. Soc. 2003, 125, 602-610; b) M. P. Cifuentes, C. E. Powell, J. P. Morrall, A. M. McDonagh, N. T. Lucas, M. G. Humphrey, M. Samoc, S. Houbrechts, I. Asselberghs, K. Clays, A. Persoons, T. Isoshima, J. Am. Chem. Soc. 2006, 126, 10819 10832.

[24] A. M. McDonagh, C. E. Powell, J. P. Morrall, M. P. Cifuentes, M. G. Humphrey, Organometallics 2003, 22, 1402-1413.

[25] a) C. E. Powell, M. G. Humphrey, M. P. Cifuentes, J. P. Morrall, M. Samoc, B. Luther-Davies, J. Phys. Chem. A 2003, 107, 11264-1266; b) G. T. Dalton, M. P. Cifuentes, S. Petrie, R. Stranger, M. G. Humphrey, M. Samoc, J. Am. Chem. Soc. 2007 129, 11882-11883.

[26] M. Sheik-Bahae, A. A. Said, T. Wei, D. J. Hagan, E. W. van Stryland, IEEE J. Quantum Electr. 1990, 26, 760-769.

[27] A. M. McDonagh, M. G. Humphrey, M. Samoc, B. Luther-Davies, Organometallics 1999, 18, 5195-5197. 


\section{Entry for the Table of Contents}

\section{FULL PAPER}

(4-Formylphenylethynyl)ruthenium complexes such as that at right are shown to undergo "chemistry-oncomplex" Horner-Wadsworth-Emmons coupling, affording a range of tri- and tetra-ruthenium-functionalized star molecules and a nonaruthenium dendrimer. The products are NLOactive, with linear optical properties that are redox-switchable.
Zhiwei Chen, Christopher J. Jeffery, Mahbod Morshedi, Graeme J. Moxey, Adam Barlow, Xinwei Yang, Bandar A. Babgi, Gulliver T. Dalton, Michael D. Randles, Matthew K. Smith, Chi Zhang, Marek Samoc, Marie P. Cifuentes, Mark G. Humphrey*

\section{Page No.-Page No.}

Syntheses, Electrochemical, Linear Optical, and Cubic NLO Properties of Ruthenium Alkynyl-Functionalized Oligo(phenylenevinylene) Stars 